\title{
Sectorrapportage Hoger Gezondheidszorgonderwijs en Hoger Sociaal-Agogisch Onderwijs
}

Citation for published version (APA):

Allen, J. P., Ramaekers, G. W. M., \& Verhagen, A. M. C. (2013). Sectorrapportage Hoger

Gezondheidszorgonderwijs en Hoger Sociaal-Agogisch Onderwijs. ROA. ROA Reports No. 005 https://doi.org/10.26481/umarep.2013005

Document status and date:

Published: 01/01/2013

DOI:

10.26481/umarep.2013005

Document Version:

Publisher's PDF, also known as Version of record

\section{Please check the document version of this publication:}

- A submitted manuscript is the version of the article upon submission and before peer-review. There can be important differences between the submitted version and the official published version of record.

People interested in the research are advised to contact the author for the final version of the publication, or visit the DOI to the publisher's website.

- The final author version and the galley proof are versions of the publication after peer review.

- The final published version features the final layout of the paper including the volume, issue and page numbers.

Link to publication

\footnotetext{
General rights rights.

- You may freely distribute the URL identifying the publication in the public portal. please follow below link for the End User Agreement:

www.umlib.nl/taverne-license

Take down policy

If you believe that this document breaches copyright please contact us at:

repository@maastrichtuniversity.nl

providing details and we will investigate your claim.
}

Copyright and moral rights for the publications made accessible in the public portal are retained by the authors and/or other copyright owners and it is a condition of accessing publications that users recognise and abide by the legal requirements associated with these

- Users may download and print one copy of any publication from the public portal for the purpose of private study or research.

- You may not further distribute the material or use it for any profit-making activity or commercial gain

If the publication is distributed under the terms of Article $25 \mathrm{fa}$ of the Dutch Copyright Act, indicated by the "Taverne" license above, 
Sectorrapportage Hoger

Gezondheidszorgonderwijs en Hoger Sociaal-Agogisch Onderwijs

Jim Allen

Ger Ramaekers

Annelore Verhagen

ROA-R-2013/5 


\section{Colofon}

(C) Researchcentrum voor Onderwijs en Arbeidsmarkt (ROA). Niets uit deze uitgave mag op enige manier worden verveelvoudigd zonder voorafgaande schriftelijke toestemming van de directeur van het ROA.

\section{Researchcentrum voor Onderwijs en Arbeidsmarkt}

School of Business and Economics

Maastricht University

\section{Vormgeving}

ROA secretariaat, Maastricht

\section{Verkoop}

Researchcentrum voor Onderwijs en Arbeidsmarkt email: secretary-roa-sbe@maastrichtuniversity.nl website: www.roa.nl

ISBN: 978-90-532I-510-4

februari 2013 


\section{Inhoud}

1 Inleiding 1

2 De arbeidsmarkt voor afgestudeerden van het HGZO en HSAO 7

$\begin{array}{lll}2.1 & \text { Samenvatting uitkomsten per opleidingscluster } & 7\end{array}$

2.2 Arbeidsmarkttrends 9

3 Arbeidsmarktperspectieven $\quad 21$

4 Vereiste competenties voor afgestudeerden van het HGZO en HSAO 25

$\begin{array}{lll}4.1 & \text { Trends en ontwikkelingen } & 25\end{array}$

$\begin{array}{ll}4.2 \text { Vereist niveau competenties } & 27\end{array}$

$\begin{array}{lll}4.3 \text { Competentietekorten } & 31\end{array}$

5 Grenzen tussen $\mathrm{HBO}$ en $\mathrm{MBO} \quad 35$

5.1 HGZO'ers en HSAO'ers in MBO-functies $\quad 35$

5.2 MBO'ers in HBO-functies 36

6 Conclusie

$\begin{array}{ll}\text { Literatuur } & 41\end{array}$

$\begin{array}{ll}\text { Bijlagen } & 43\end{array}$ 



\section{Inleiding}

De HBO-Monitor vierde in 2010 haar 20-jarige bestaan. In de eerste twintig jaar van de $\mathrm{HBO}-$ Monitor is op verschillende manieren gerapporteerd over de aansluiting tussen het $\mathrm{HBO}$ en de arbeidsmarkt, over de vraag wat de HBO-studenten tijdens hun studie hebben geleerd en over de vraag hoe zij de gevolgde opleiding beoordelen. Hierbij is vooral gericht gerapporteerd op landelijk niveau en op het niveau van de onderwijsinstelling. De tussenliggende laag, de afzonderlijke sectoren, (met uitzondering van de sector kunst), zijn daarbij zelden als insteek gebruikt (met uitzondering van het eerste jaar van de HBO-Monitor). Afgezien voor de sector Kunst, wordt voor de resterende zes sectoren: Economie, Gezondheidszorg, Landbouw, Pedagogisch, Sociaalagogisch en Techniek wordt in het kader van het 20-jarige bestaan dan ook een rapport geschreven met hun sector als centraal ankerpunt. Vanuit dit perspectief is de voorliggende rapportage specifiek gericht op de $\mathrm{HBO}$-sectoren Hoger Gezondheidszorg Onderwijs (HGZO) en Hoger Sociaalagogisch Onderwijs (HSAO). Hierbij staan de implicaties van recente alsook toekomstige arbeidsmarktontwikkelingen in de sector op de gevraagde competenties van afgestudeerden centraal. Zo wordt achterhaald op welke competenties het onderwijsveld zich de komende jaren zou moeten richten om afgestudeerden optimaal voor te kunnen bereiden op hun beroepsloopbaan in de zorg- en welzijnssector. De context van deze rapportage wordt gevormd door de strategische agenda $\mathrm{HO}$ en het hoofdlijnenakkoord tussen de $\mathrm{HBO}$-raad en het Ministerie van Onderwijs, Cultuur en Wetenschap (Ministerie van OC\&W, 20II). Hierin worden afspraken gemaakt over het met een zekere regelmaat uitvoeren van sectorale verkenningen. De huidige rapportage in het kader van 20 jaar $\mathrm{HBO}-$ Monitor levert relevant materiaal voor die sectorale verkenningen.

In dit rapport worden de twee sectoren HGZO en HSAO behandeld, omdat ze inhoudelijk verwant zijn (beiden richten zich op de zorg). De grens tussen gezondheidsproblematiek en sociale problematiek kan niet altijd eenduidig worden getrokken, en er is sprake van een toenemende verschuiving van zorg binnen de instelling naar zorg bij mensen thuis waarbij de nadruk verschuift van zorg en behandeling naar begeleiding en ondersteuning bij zelfredzaamheid.

Er is natuurlijk ook sprake van differentiatie binnen deze sectoren, met name binnen het HGZO. Om recht te doen aan deze heterogeniteit wordt in dit rapport gebruik gemaakt van een nadere clustering van opleidingen binnen de laatstgenoemde sector. Een onderscheid wordt gemaakt tussen verpleegkunde, bewegingsstudies, paramedi- 
sche opleidingen en overige HGZO opleidingen. De indeling van opleidingen in deze vier clusters staat in bijlage I. Met uitzondering van de Masteropleiding Advanced Nursing Practice, wordt in het rapport uitsluitend over bacheloropleidingen gerapporteerd. De overige masteropleidingen zijn onvoldoende representatief in de data vertegenwoordigd om hierover op betrouwbare wijze te kunnen rapporteren.

\section{Leeswijzer}

Als uitgangspunt voor voorliggende sectorrapportage wordt in hoofdstuk I allereerst kort een algemeen beeld van deze sector geschetst. Vervolgens wordt in hoofdstuk 2 aan de hand van een breed scala aan indicatoren de arbeidsmarktsituatie voor recent afgestudeerden van het Hoger Gezondheidszorg Onderwijs en Hoger Sociaal agogisch Onderwijs beschreven. Ten eerste wordt een aantal trends beschreven die betrekking hebben op de kans op werk van afgestudeerden, en van de werkende de belangrijkste baankenmerken. Hierna wordt in hoofdstuk 3 stilgestaan bij de arbeidsmarktdynamiek van de zorg- en welzijnssector. Dit wordt gedaan aan de hand van de verwachte arbeidsmarktperspectieven voor afgestudeerden van het HGZO en HSAO. In hoofdstuk 4 wordt ingegaan op de competenties die recent afgestudeerden dienen te bezitten. Tot slot worden in hoofdstuk 5 de grenzen tussen $\mathrm{HBO}$ en $\mathrm{MBO}$ zorg en welzijnsstudies geanalyseerd, waarna in hoofdstuk 6 de belangrijkste conclusies op een rij worden gezet. In de bijlage worden de resultaten voor enkele kernindicatoren uitgesplitst naar HGZO en HSAO Bachelor-opleidingen.

\section{HGZO en HSAO cijfermatig in beeld}

Wie kiezen nu precies voor opleidingen in de zorg- en welzijnssector? Tabel I.I geeft een nadere typering van de afgestudeerden van het HGZO en HSAO in termen van geslacht, leeftijd, hoogst voltooide vooropleiding en vervolgopleiding. Ter vergelijking worden ook de cijfers voor het $\mathrm{HBO}$ als geheel gepresenteerd. Net als alle andere cijfers in dit rapport hebben deze cijfers uitsluitend betrekking op afgestudeerden van voltijd $\mathrm{HBO}$-opleidingen. 
Tabel 1.1

Afgestudeerden HBO naar geslacht, leeftijd, vooropleiding en vervolgopleiding, 2006-2010

\begin{tabular}{|c|c|c|c|c|c|c|}
\hline & & HGZO & & & HSAO & HBO totaal \\
\hline & Verpleegkunde & $\begin{array}{r}\text { Bewegings- } \\
\text { studies }\end{array}$ & Paramedisch & Overig & & \\
\hline Vrouw (\%) & 90.1 & 96.2 & 69.4 & 83.7 & 88.4 & 55.8 \\
\hline Leeftijd (gem.) & 25.2 & 24.7 & 24.7 & 26.4 & 24.9 & 25.2 \\
\hline Allochtoon (\%) & & & & & & \\
\hline westerse & 4.2 & 14.0 & 10.2 & 5.5 & 5.6 & 7.2 \\
\hline niet-westerse & 3.3 & 1.4 & 1.9 & 6.5 & 7.7 & 6.2 \\
\hline Hoogst voltooide vooropleiding & & & & & & \\
\hline HAVO & 56.3 & 46.2 & 47.5 & 47.8 & 49.3 & 48.9 \\
\hline VWO & 14.6 & 30.2 & 28.4 & 16.8 & 11.6 & 16.7 \\
\hline$M B O$ & 22.5 & 12.1 & 12.0 & 23.0 & 32.8 & 26.8 \\
\hline HBO & 5.7 & 4.2 & 8.3 & 10.5 & 4.0 & 5.3 \\
\hline andere vooropleiding & 0.8 & 7.3 & 3.8 & 1.9 & 2.2 & 2.3 \\
\hline Vervolgopleiding gevolgd (\%) & 24.1 & 13.5 & 32.5 & 16.0 & 17.4 & 22.1 \\
\hline
\end{tabular}

Bron: HBO-Monitor 2006-2010

Tabel I.I laat op overtuigende wijze zien dat de uitstroom uit beide sectoren wordt gedomineerd door vrouwen. Alleen bij de paramedische opleidingen van het HGZO is sprake van een iets evenwichtiger verhouding tussen mannen en vrouwen, maar zelfs hier is bijna zeven op de tien afgestudeerden vrouw, tegenover $55 \%$ voor het $\mathrm{HBO}$ als geheel. De sectoren en clusters ontlopen elkaar niet veel in termen van leeftijd: alleen de afgestudeerden "overige" HGZO zijn gemiddeld iets ouder dan die van de andere sectoren/clusters. Opvallend is dat bij bewegingsstudies en paramedische opleidingen een relatief hoog aandeel van de uitstroom westerse allochtoon is, terwijl juist een relatief laag aandeel niet-westerse allochtoon is. Beide groepen allochtonen zijn iets ondervertegenwoordigd bij verpleegkunde opleidingen. Relatief veel afgestudeerden van bewegingsstudies en paramedische opleidingen hebben een vwo vooropleiding, en relatief weinig een $\mathrm{MBO}$ vooropleiding. Relatief veel afgestudeerden van paramedische opleidingen stromen door naar een vervolgopleiding, terwijl bij bewegingsstudies het aandeel doorstudeerders juist iets lager ligt dan het $\mathrm{HBO}$-gemiddelde.

Om een beeld te krijgen van de werkgelegenheid voor recent afgestudeerden van het HGZO en HSAO, staan in tabel I.2 de branches waarin de afgestudeerden van beide sectoren het vaakst werken. Deze tabel laat zien dat, zoals zou mogen worden verwacht, de meeste afgestudeerden van het HGZO werk vinden in de gezondheidszorg. Het type organisatie binnen de gezondheidszorg verschilt echter sterk naar opleidingscluster. Afgestudeerden van verpleegkunde opleidingen werken overwegend in ziekenhuizen, maar zijn in mindere mate ook vaak te vinden in organisaties gericht op het verzorgen van ouderen en gehandicapten. Afgestudeerden van de andere HGZOclusters werken ook relatief vaak in ziekenhuizen, maar zijn vaker te vinden in andere typen organisaties. Bij bewegingsstudies en paramedische opleidingen zijn dat vooral organisaties gericht op het aanbieden van zorg zonder overnachting. 
Tabel 1.2

Aandeel werkende recent afgestudeerden van het HGZO en HSO per branche, 2006-2010 (\%)

\begin{tabular}{|c|c|c|c|c|c|c|}
\hline & \multicolumn{4}{|c|}{ HGZO } & \multirow[t]{2}{*}{ HSAO } & \multirow[t]{2}{*}{ HBO totaal } \\
\hline & $\begin{array}{r}\text { Verpleeg- } \\
\text { kunde }\end{array}$ & $\begin{array}{r}\text { Bewegings } \\
\text { studies }\end{array}$ & Paramedisch & Overig & & \\
\hline Ziekenhuizen & 65.6 & 16.7 & 11.9 & 28.4 & 11.4 & 5.7 \\
\hline $\begin{array}{l}\text { Paramedische praktijken en overige } \\
\text { gezondheidszorg zonder overnachting }\end{array}$ & 4.3 & 37.3 & 66.4 & 19.2 & 1.8 & 3.9 \\
\hline $\begin{array}{l}\text { Maatschappelijke dienstverlening zonder } \\
\text { overnachting niet specifiek gericht op ouderen } \\
\text { en gehandicapten }\end{array}$ & 1.4 & 1.2 & 1.0 & 2.7 & 23.7 & 3.4 \\
\hline Verpleeghuizen & 2.0 & 15.0 & 6.0 & 2.6 & 0.7 & 0.7 \\
\hline Medische en tandheelkundige praktijken & 3.8 & 1.0 & 0.6 & 16.5 & 2.5 & 0.9 \\
\hline $\begin{array}{l}\text { Maatschappelijke dienstverlening zonder } \\
\text { overnachting gericht op ouderen en } \\
\text { gehandicapten }\end{array}$ & 10.4 & 2.3 & 0.7 & 4.4 & 4.7 & 1.2 \\
\hline $\begin{array}{l}\text { Verpleging, verzorging en begeleiding met } \\
\text { overnachting }\end{array}$ & 2.7 & 3.7 & 1.6 & 2.8 & 9.1 & 1.4 \\
\hline $\begin{array}{l}\text { Jeugdzorg en maatschappelijke opvang met } \\
\text { overnachting }\end{array}$ & 0.8 & 0.4 & 0.2 & 0.2 & 10.6 & 1.3 \\
\hline $\begin{array}{l}\text { Huizen en dagverblijven voor verstandelijk } \\
\text { gehandicapten en psychiatrische cliënten }\end{array}$ & 1.8 & 0.5 & 0.5 & 0.3 & 5.4 & 0.7 \\
\hline Primair en speciaal onderwijs & 0.1 & 5.3 & 0.6 & 0.3 & 1.6 & 10.8 \\
\hline
\end{tabular}

Aandeel tenminste $5 \%$ in $\mathrm{HGZO}$ en/of HSAO

Bron: HBO-Monitor 2006-2010

De gezondheidszorg is ook belangrijk voor afgestudeerden van het HSAO, maar iets meer van deze afgestudeerden vinden werk in de maatschappelijke dienstverlening en de verpleging/verzorging. Deze cijfers laten zien dat er zoals verwacht enige overlap is tussen het werkgebied van afgestudeerden van beide sectoren, maar dat beide hun eigen kenmerkend werkdomein kennen. Dat geldt ook voor de clusters binnen het HGZO. Het sterke aandeel van beide groepen in de gezondheidszorgbranche is overigens niet verwonderlijk, gezien het feit dat deze branche een zeer belangrijke en grote sector is in de Nederlandse economie. Zo neemt deze branche ca. IO\% van het BNP voor zijn rekening. Ruim I,2 miljoen mensen, waaronder zeer veel HBO'ers, verdienen hun brood in de zorgsector en nog eens 2,5 miljoen mensen zijn vrijwilliger (Rabobank, 20IO).

Een andere manier om naar werkgelegenheid te kijken is om te zien in welke branches afgestudeerden van het HGZO en HSAO de dominante groep zijn. Tabel I.3 geeft hiervan een beeld, door Io branches te presenteren met het hoogste aandeel afgestudeerden van het $\mathrm{HGZO} / \mathrm{HSAO}$, en waar minstens een derde van alle werkzame $\mathrm{HBO}$-afgestudeerden uit één van deze twee sectoren afkomstig is.

Hoewel de gezondheidszorg een zeer grote en belangrijke branche is in de Nederlandse economie, wordt de werkgelegenheid op HBO-niveau in verschillende soorten organisaties binnen deze branche sterk gedomineerd door afgestudeerden van deze twee sectoren. Hetzelfde geldt voor organisaties die belast zijn met verschillende vormen 
van maatschappelijke dienstverlening. Hoewel deze twee sectoren samen slechts iets meer dan een vijfde van de totale HBO-uitstroom vormen in de periode 2006-20I0, komen ze in deze branches erg weinig afgestudeerden van andere $\mathrm{HBO}$-sectoren tegen. Wel zijn er branches waarin zowel HGZO'ers alsook HSAO'ers in min of meer gelijke aantallen werken. Dit geldt voor bijvoorbeeld maatschappelijke dienstverlening zonder overnachting gericht op ouderen en gehandicapten. Daarentegen zijn er branches die sterk worden gedomineerd door één of twee opleidingsclusters binnen het HGZO, zoals verpleeghuizen en paramedische praktijken en overige gezondheidszorg zonder overnachting.

\section{Tabel 1.3}

Branches waar afgestudeerden van het HGZO/HSAO de dominante groep zijn onder HBO-afgestudeerden, 2006-2010(\%)

\begin{tabular}{|c|c|c|c|c|c|c|c|c|}
\hline & & & $\mathrm{HG}$ & & & & HSAO & HGZO/ \\
\hline & & $\begin{array}{l}\text { Verpleeg- } \\
\text { kunde }\end{array}$ & $\begin{array}{r}\text { Bewegings- } \\
\text { studies }\end{array}$ & $\begin{array}{r}\text { Para- } \\
\text { medisch }\end{array}$ & Overig & Totaal & & \\
\hline 1 & Verpleeghuizen & 10.3 & 35.7 & 29.6 & 8.1 & 83.7 & 11.2 & 94,9 \\
\hline 2 & $\begin{array}{l}\text { Jeugdzorg en maatschappelijke } \\
\text { opvang met overnachting }\end{array}$ & 2.1 & 0.5 & 0.5 & 0.3 & 3.4 & 89.8 & 93,2 \\
\hline 3 & $\begin{array}{l}\text { Huizen en dagverblijven voor } \\
\text { verstandelijk gehandicapten en } \\
\text { psychiatrische cliënten }\end{array}$ & 8.0 & 1.0 & 2.2 & 0.7 & 11.9 & 80.1 & 92 \\
\hline 4 & $\begin{array}{l}\text { Verpleging, verzorging en } \\
\text { begeleiding met overnachting }\end{array}$ & 6.5 & 4.2 & 3.8 & 4.1 & 18.6 & 71.3 & 89,9 \\
\hline 5 & $\begin{array}{l}\text { Paramedische praktijken en } \\
\text { overige gezondheidszorg zonder } \\
\text { overnachting }\end{array}$ & 3.7 & 14.9 & 55.5 & 9.9 & 84.0 & 5.1 & 89,1 \\
\hline 6 & $\begin{array}{l}\text { Maatschappelijke dienstverlening } \\
\text { zonder overnachting }\end{array}$ & 2.3 & 1.4 & 1.4 & 0.0 & 5.2 & 81.9 & 87,4 \\
\hline 7 & $\begin{array}{l}\text { Medische en tandheelkundige } \\
\text { praktijken }\end{array}$ & 14.4 & 1.8 & 2.3 & 37.6 & 56.1 & 30.9 & 87 \\
\hline 8 & $\begin{array}{l}\text { Maatschappelijke dienstverlening } \\
\text { zonder overnachting gericht op } \\
\text { ouderen en gehandicapten }\end{array}$ & 28.4 & 3.0 & 1.8 & 7.3 & 40.4 & 42.1 & 82,5 \\
\hline 9 & Ziekenhuizen & 38.1 & 4.5 & 6.7 & 9.9 & 59.2 & 21.5 & 80,7 \\
\hline 10 & $\begin{array}{l}\text { Maatschappelijke dienstverlening } \\
\text { zonder overnachting niet specifiek } \\
\text { gericht op ouderen en }\end{array}$ & 1.3 & 0.6 & 0.9 & 1.6 & 4.4 & 75.1 & 79,5 \\
\hline
\end{tabular}

Aandeel tenminste $33 \% \mathrm{HGZO} \mathrm{en/of} \mathrm{HSAO}$

Bron: HBO-Monitor 2006-2010

Tabel I.4 geeft de belangrijkste beroepen weer voor recent afgestudeerden van het HGZO/HSAO tussen 2006 en 20IO, gesorteerd naar het percentage van de totale groep $\mathrm{HGZO/HSAO}$ afgestudeerden dat I,5 jaar na afstuderen in deze beroepen werkzaam is. Recent afgestudeerden van de $\mathrm{HBO}$ zorg- en welzijnsstudies komen veruit het vaakst terecht in een beroep als therapeut/verpleegkundige of sociaal-cultureel werker: bijna $70 \%$ van de afgestudeerde $\mathrm{HGZO/HSAO'ers} \mathrm{is} \mathrm{ongeveer} \mathrm{I,} 5$ jaar na 
afstuderen werkzaam een van deze twee beroepsgroepen. Dat is bijna vier keer zoveel als het HBO-gemiddelde. Op de derde plaats wat betreft beroepen waar veel HBO zorg- en welzijnsstudenten terecht komen, staat het verzorgend personeel, hoewel hier slechts $5,9 \%$ van alle HGZO/HSAO'ers werkzaam is. De overige populaire beroepen hebben dan ook weliswaar niet allemaal even veel met zorg- en welzijn te maken, maar daar werkt dan ook minder dan $5 \%$ van de HGZO/HSAO afgestudeerden.

\section{Tabel 1.4}

Aandeel werkende recent afgestudeerden van het HGZO/HSAO per beroep, 2006-2010 (\%)

\begin{tabular}{|c|c|c|c|c|c|c|c|c|c|}
\hline & & & & 3Z0 & & & HSAO & $\mathrm{HGZO/}$ & HBO \\
\hline & & $\begin{array}{r}\text { Verpleeg- } \\
\text { kunde }\end{array}$ & $\begin{array}{r}\text { Bewe- } \\
\text { gings- } \\
\text { studies }\end{array}$ & $\begin{array}{r}\text { Para- } \\
\text { medisch }\end{array}$ & Overig & Totaal & & & \\
\hline 1 & $\begin{array}{l}\text { Therapeuten en verpleeg- } \\
\text { kundigen }\end{array}$ & 71,0 & 83,3 & 90,4 & 50,0 & 75,0 & 3,9 & 38,0 & 8,2 \\
\hline 2 & Sociaal-cultureel werkers & 4,1 & 3,1 & 1,3 & 4,5 & 3,1 & 50,3 & 27,6 & 8,9 \\
\hline 3 & Verzorgend personeel & 1,8 & 0,2 & 0,4 & 1,2 & 1,0 & 10,5 & 5,9 & 1,8 \\
\hline 4 & $\begin{array}{l}\text { Activiteitenbegeleiders } \\
\text { en medewerkers } \\
\text { arbeidsbemiddeling }\end{array}$ & 0,8 & 0,2 & 0,3 & 1,0 & 0,6 & 8,4 & 4,7 & 1,4 \\
\hline 5 & $\begin{array}{l}\text { Hulpkrachten horeca en } \\
\text { verzorging }\end{array}$ & 1,9 & 1,0 & 0,3 & 0,3 & 0,9 & 5,2 & 3,2 & 1,1 \\
\hline 6 & $\begin{array}{l}\text { Verplegenden en } \\
\text { doktersassistenten }\end{array}$ & 14,2 & 0,3 & 0,3 & 0,8 & 5,0 & 0,7 & 2,8 & 0,6 \\
\hline 7 & Medisch analisten & 0,9 & 4,4 & 0,4 & 19,0 & 4,8 & 0,3 & 2,5 & 1,1 \\
\hline 8 & Assistent accountants & 0,1 & 1,5 & 0,2 & 1,0 & 0,5 & 2,3 & 1,5 & 5,7 \\
\hline 9 & Commercieel medewerkers & 0,4 & 0,2 & 0,5 & 3,1 & 0,9 & 1,6 & 1,3 & 10,6 \\
\hline 10 & $\begin{array}{l}\text { Receptionisten en } \\
\text { administratieve employees }\end{array}$ & 0,1 & 0,4 & 0,2 & 1,2 & 0,4 & 1,6 & 1,0 & 1,8 \\
\hline
\end{tabular}

Bron: HBO-Monitor 2006-2010 


\section{De arbeidsmarkt voor afgestudeerden van het HGZO en HSAO}

In hoofdstuk 2 staat de arbeidsmarktintrede van recent afgestudeerden van het $\mathrm{HGZO}$ en HSAO centraal. In dit hoofdstuk komen verschillende indicatoren aan bod die een indicatie geven over de transitie van het HGZO en HSAO naar de arbeidsmarkt. Zodoende wordt een beeld verschaft van niet alleen de huidige situatie voor afgestudeerden van het HGZO en HSAO op de arbeidsmarkt, maar ook van de mate waarin die situatie stabiel is, structureel beter of slechter wordt, of gevoelig is voor de conjunctuur.

We beginnen met een korte samenvatting van de belangrijkste uitkomsten per cluster (paragraaf 2.I). Vervolgens worden de trends in detail besproken (paragraaf 2.2). In de bijlage zijn voor de periode 2006-20Io de kernindicatoren werkloosheid, werkzaam in kerndomein, inkomen huidige baan, spijt van de gekozen opleiding en tevredenheid met huidige baan weergegeven voor de afzonderlijke Bachelor-opleidingen van het Hoger Gezondheidszorg Onderwijs en het Hoger Sociaal-Agogisch Onderwijs. Deze cijfers worden afgezet tegen het HGZO/HSAO gemiddelde en het $\mathrm{HBO}$ gemiddelde.

\subsection{Samenvatting uitkomsten per opleidingscluster}

\section{HGZO-verpleegkunde}

Afgestudeerden van HGZO-verpleegkunde opleidingen hebben weinig problemen met het vinden van werk na het verlaten van de opleiding, en hebben ook weinig last van de conjunctuur. Tot op zekere hoogte wordt deze hoge mate van werkzekerheid verkregen door het vaker verrichten van werk buiten het eigen kerndomein. Dat wil zeggen dat zij banen aanvaarden waarvoor door de werkgever een lager niveau en/ of een andere richting werd vereist. Ook het oordeel over de aansluiting tussen de gevolgde opleiding en de huidige functie laat relatief vaak te wensen over. Hoewel er relatief zelden in een tijdelijk en/of parttime dienstverband wordt gewerkt, is onder afgestudeerden van deze cluster het aandeel van beide in de loop van de jaren fors toegenomen, waardoor een deel van de voorsprong ten opzichte van de overige clusters verdwenen is. De beloning is relatief laag ten opzichte van de overige clusters, maar een lichte verbetering over de jaren heeft dit op het niveau gebracht van het $\mathrm{HBO}$ als geheel. Vergeleken met de meeste andere clusters en met het $\mathrm{HBO}$ als geheel is men tamelijk tevreden met de huidige baan, en deze tevredenheid lijkt minder te 
fluctueren met de conjunctuur dan gebruikelijk is bij andere opleidingstypen. Het oordeel over de carrièremogelijkheden in de huidige functie zijn uitgesproken positief, en worden de laatste jaren nog veel beter. Net als bij de andere HGZO clusters en het HSAO is de deelname aan bijscholing onder afgestudeerden van HGZOverpleegkunde opleidingen in de loop der jaren flink toegenomen. Men toont zich ook over de jaren steeds tevredener met de opleidingskeuze.

\section{HGZO-bewegingsstudies}

Net als bij HGZO-verpleegkunde is de werkloosheid onder afgestudeerden van HGZO-bewegingsstudies doorgaans laag, maar anders dan eerstgenoemde cluster heeft men wel wat last van de conjunctuur. Ook in tegenstelling tot HGZOverpleegkunde werken vrijwel alle afgestudeerden van deze cluster in hun eigen kerndomein. Ze zijn ook tamelijk positief over de aansluiting tussen de HBO-opleiding en de huidige functie, hoewel dit oordeel in de loop der jaren minder positief is geworden. Men werkt relatief vaak in tijdelijke en/of parttime dienstverbanden. Qua beloning zijn afgestudeerden van deze cluster als middenmoters te omschrijven in vergelijking met de overige clusters, hoewel ze gemiddeld nog altijd iets meer verdienen dan het HBO-gemiddelde. Men is tamelijk tevreden met de huidige functie, en hoewel de tevredenheid over de carrièremogelijkheden aan de lage kant is, neemt dit fors toe in de tijd. Ook de deelname aan bijscholing neemt flink toe, waardoor deze cluster anno 2010 tot de clusters behoort waar het meest aan bijscholing wordt gedaan. Men toont consistent een hoge mate van tevredenheid achteraf met de opleidingskeuze.

\section{HGZO-paramedisch}

De werkloosheid onder afgestudeerden van HGZO-paramedisch is iets hoger dan bij de meeste andere clusters, en is met name veel gevoeliger voor de conjunctuur. Desalniettemin werken vrijwel alle afgestudeerden van deze cluster in hun eigen kerndomein. Het oordeel over de aansluiting tussen opleiding en de huidige functie wordt over de jaren iets minder positief, maar is nog altijd positiever dan alle andere clusters. Men werkt relatief vaak in tijdelijke en/of parttime functies. Het gemiddelde uurloon van afgestudeerden van deze cluster is veruit het hoogste van alle clusters, en ligt stabiel ruim boven het HBO-gemiddelde. Ook de baantevredenheid ligt hoog, en het oordeel over de carrièremogelijkheden in de huidige functie verbetert zeer snel, waardoor anno 2010 dit oordeel onder afgestudeerden van deze cluster veruit het positiefst is van alle clusters. Er wordt ook relatief zeer vaak geïnvesteerd in bijscholing, en vrijwel iedereen is achteraf tevreden met de opleidingskeuze.

\section{HGZO-overig}

Deze gemengde cluster toont een toenemende werkloosheid, maar ook een toenemend aandeel dat werkzaam is binnen het eigen kerndomein. Net als bij de andere clusters neemt het aandeel dat tevreden is met de aansluiting tussen de opleiding en 
de huidige functie af in de tijd. Ondanks deze veranderingen zijn afgestudeerden van deze cluster als lage middenmoters te omschrijven op deze indicator. Datzelfde geldt voor het aandeel dat werkzaam is in tijdelijke en/of parttime dienstverbanden, waarbij geldt dat het aandeel van beide toeneemt in de tijd. Ook qua beloning zitten afgestudeerden van deze cluster in een middenpositie, en hoewel dit wat meer fluctueert van jaar tot jaar dan bij de meest clusters, ligt het beloningsniveau nog altijd ruim boven het HBO-gemiddelde. De baantevredenheid schommelt ook iets op en neer, zonder veel af te wijken van haar middenpositie ten opzichte van de andere clusters. De tevredenheid met de carrièremogelijkheden nam toe in de eerste helft van het afgelopen decennium, maar bleef stabiel vanaf 2005-2006. Hoewel er iets meer wordt geïnvesteerd in bijscholing in de loop der jaren ligt dit percentage hier van alle clusters het laagst. Men heeft ook relatief vaak spijt achteraf van de gekozen opleiding.

HSAO

Afgestudeerden van het HSAO zijn relatief vaak werkloos, en hebben vrij veel last van de conjunctuur. Ze werken vaker dan afgestudeerden buiten hun eigen kerndomein, en geven vaak aan dat de aansluiting tussen de opleiding en de huidige functie minder dan optimaal is. Ze werken relatief vaak in tijdelijke en/of parttime functies. Hun uurloon ligt gemiddeld relatief laag, hoewel dit in de loop der jaren wat bijgetrokken is. Ze zijn het minst tevreden met de huidige functie en zien relatief weinig carrièreperspectieven In de loop der jaren is de deelname aan bijscholing iets sneller toegenomen dan bij de meeste HGZO-clusters. Alles bij elkaar genomen is het weinig verrassend dat een relatief hoog aandeel HSAO-ers aangeeft achteraf spijt te hebben met de gekozen opleiding.

\subsection{Arbeidsmarkttrends}

De indicatoren die achtereenvolgens aan bod komen zijn het werkloosheidspercentage, het percentage tijdelijke contracten, deeltijdwerkers, het niveau en de richting van de huidige functie, het percentage dat de aansluiting tussen onderwijs en arbeidsmarkt als voldoende of goed betiteld, de beloning, de tevredenheid met de huidige baan, het percentage dat spijt heeft van de gevolgde opleiding en tot slot het percentage dat een cursus of bedrijfsopleiding gevolgd heeft. Voor elke indicator wordt de trend voor de recent afgestudeerden van het HGZO (naar opleidingscluster) en HSAO afgezet tegen de trend van de totale groep recent afgestudeerde HBO'ers. De data hebben betrekking op de periode 1998-20I0. De gepresenteerde informatie betreft het gemiddelde van de desbetreffende sectoren/clusters en kan uiteraard verschillen voor de onderliggende opleidingen. ${ }^{\mathrm{I}}$

I. Voor meer gedetailleerde informatie op het niveau van afzonderlijke opleidingen over afgestudeerden van het HGZO en HSAO wordt verwezen naar de HBO-Monitor Kerncijfers Online. Deze zijn te vinden op www.roa.unimaas.nl/kerncijfers.htm. 


\section{Werkloosheid}

Zoals zou worden verwacht is het werkloosheidspercentage sterk afhankelijk van de stand van de conjunctuur. Er zijn echter sterke verschillen tussen de clusters. Over de hele linie ligt de werkloosheid bij het HGZO relatief laag in vergelijking met het $\mathrm{HBO}$ als geheel. Wel zijn er belangrijke verschillen tussen de HGZO-clusters. Afgestudeerden van HGZO-verpleegkunde zijn het minst vaak werkloos en hebben het minst last van conjunctuur. Bij HGZO-bewegingsstudies is de werkloosheid ook laag, maar wel gevoeliger voor conjunctuur. Paramedische opleidingen en HSAO tonen gemiddeld een hogere werkloosheid en een sterkere conjunctuurgevoeligheid. Overige HGZO-opleidingen lijken zwaar te zijn getroffen door de recente crisis (zie de piek in het werkloosheidspercentage in 2008/2009), maar hebben zich in 2010 goed hersteld. Zie de bijlage voor de werkloosheidspercentages voor de $\mathrm{HGZO}$ en HSAO Bachelor-opleidingen.

Figuur 2.1

Ontwikkeling werkloosheidspercentage op enquêtemoment, 1998-2010

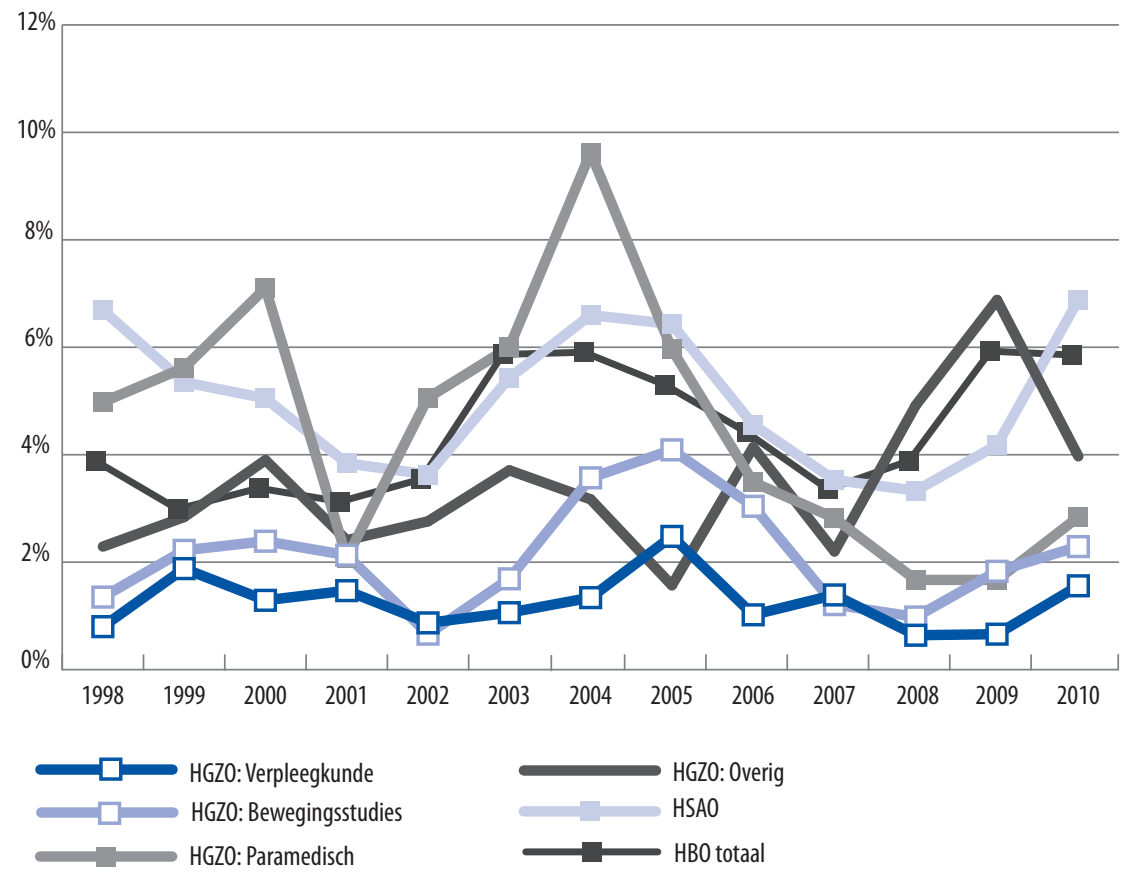

Bron: HBO-Monitor 1998-2010

\section{Tijdelijke aanstelling}

Figuur 2.2 laat de trend in het aandeel werkende afgestudeerden zien dat op het moment van de enquête een tijdelijke aanstelling had. Hieruit blijkt dat zowel voor het $\mathrm{HBO}$ als geheel als voor de meeste clusters dit aandeel fors is veranderd over de 
jaren. Er lijkt zowel een conjuncturele als een structurele component te zijn van deze verandering. In de eerste jaren van deze eeuw is dit percentage namelijk eerst gedaald, en na een stijging in de jaren daarna, was ook in de periode 2006-2008 sprake van een lichte daling. Deze was echter van korte duur, en de laatste jaren is het aandeel weer fors gestegen, in de meeste gevallen tot het hoogst niveau in de hele periode. Interessant is het feit dat deze stijging het sterkst is geweest voor clusters die voorheen weinig te maken hadden met tijdelijke aanstellingen, zoals HGZO-verpleegkunde en HGZO-overig. De clusters die aan het eind van de vorige eeuw het vaakst te maken hadden met tijdelijke aanstellingen - HGZO-paramedisch en HSAO - zijn veel minder gestegen op deze indicator.

\section{Figuur 2.2}

Trend tijdelijke aanstelling (\%), 1998-2010

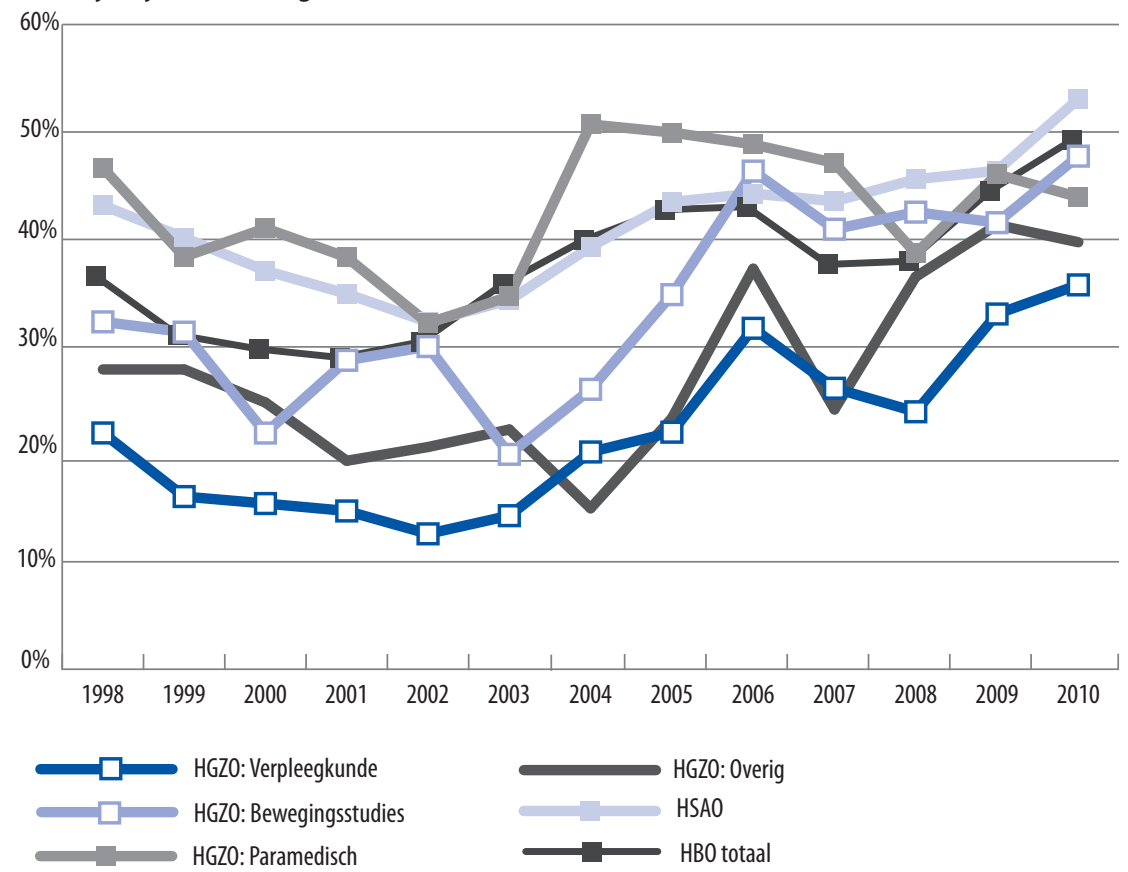

Bron: HBO-Monitor 1998-2010

\section{Parttime werk}

Recent afgestudeerden van het HGZO en HSAO werken vaker dan gemiddeld in deeltijd. Onder deeltijd wordt verstaan dat ze minder dan 32 uur per week werken. Hoewel er sprake lijkt te zijn van een lichte conjuncturele invloed, is er sinds 2000 wel een stijgende trend zichtbaar in het percentage $\mathrm{HGZO}$ en HSAO afgestudeerden dat in deeltijd werkt, en hetzelfde geldt voor de totale groep HBO afgestudeerden. 
Afgestudeerden van HGZO Bewegingsstudies, HGZO Paramedische studies en HSAO werken de gehele periode het vaakst in deeltijd: meer dan de helft van de werkende afgestudeerden van deze studierichtingen geeft aan I.5 jaar na afstuderen een parttime aanstelling te hebben. In 2008 werkte zelfs maar liefst $80 \%$ van de werkende afgestudeerden van HGZO Bewegingsstudies in deeltijd. Sinds 2005 heeft ook meer dan de helft van de werkende afgestudeerde verpleegkundigen een parttime aanstelling.

\section{Figuur 2.3}

Parttime aanstelling, 1998-2010 (\%)

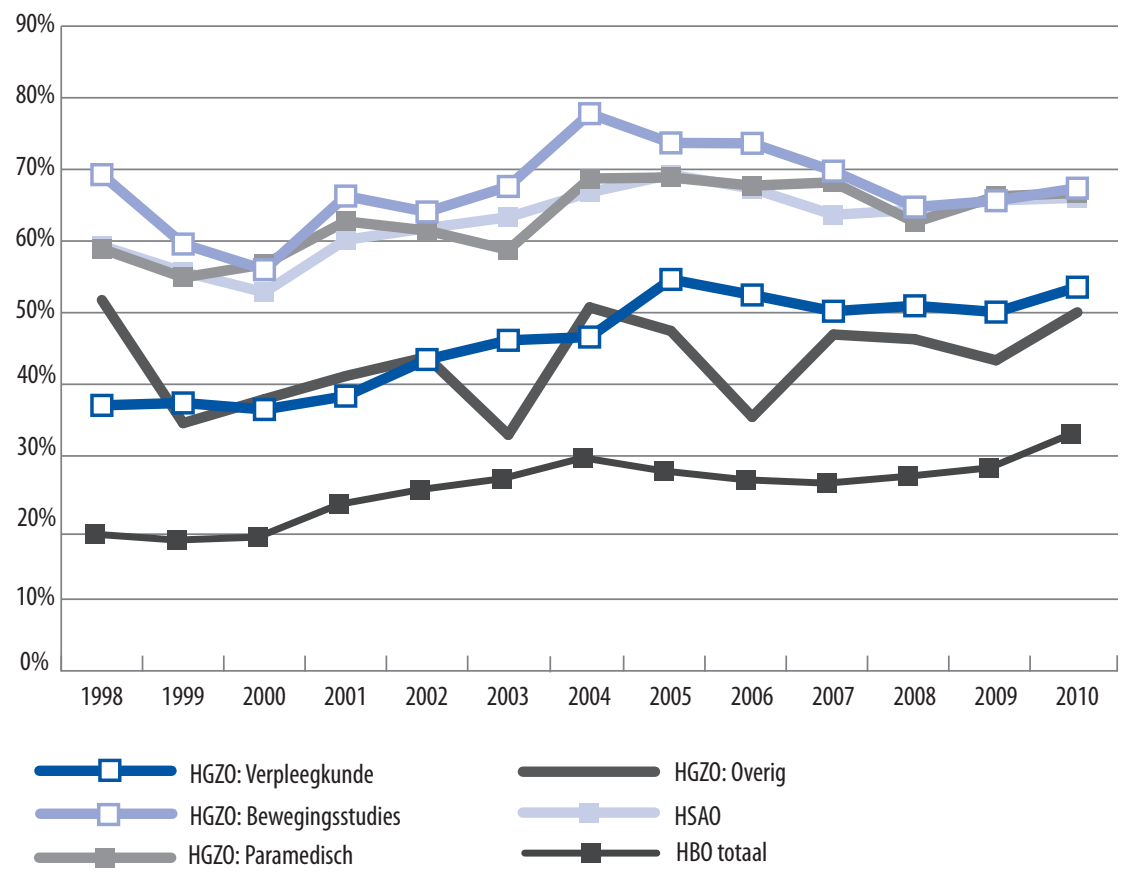

Bron: HBO-Monitor 1998-2010

\section{Niveau en richting huidige functie}

Door verdringingseffecten op de arbeidsmarkt is het mogelijk dat recent afgestudeerden noodgedwongen genoegen moeten nemen met een functie die onder hun niveau is of die buiten hun vakgebied is. Wanneer opleidingsniveau en -richting gecombineerd worden, kan achterhaald worden of de recent afgestudeerden binnen hun kerndomein werkzaam zijn. Met een baan binnen het kerndomein wordt bedoeld dat iemand een baan heeft op minimaal zijn eigen opleidingsniveau, in dit geval HBO, en tegelijkertijd in dezelfde of verwante richting als de voltooide opleidingsrichting.

Ten opzichte van het $\mathrm{HBO}$ gemiddelde werken recent afgestudeerden van het HGZO vlak na afstuderen relatief vaak binnen hun eigen kerndomein, terwijl afgestudeerden 
van het HSAO ten opzichte van het $\mathrm{HBO}$ gemiddelde juist relatief weinig binnen hun kerndomein werken. Gezien de specialistische aard van het HGZO is het niet verwonderlijk dat er dusdanig veel afgestudeerden een baan binnen het kerndomein weten te vinden. Afgestudeerden van het $\mathrm{HSAO}$ werken weliswaar relatief minder vaak binnen hun kerndomein, maar hebben wel veel vaker dan gemiddeld een baan binnen de zorg- en welzijnssector waarvoor een lager niveau dan $\mathrm{HBO}$ wordt vereist ('alleen eigen richting'). Dit betekent dat afgestudeerden van alle $\mathrm{HBO}$ zorg- en welzijnsstudies vaker dan gemiddeld binnen hun opleidingsrichting werkzaam zijn, maar dat de afgestudeerde HSAO'ers vergeleken met de HGZO afgestudeerden vaker uitwijken naar een functie onder hun niveau. In Bijlage 2 zijn de resultaten met betrekking tot het percentage dat binnen het kerndomein werkzaam is, weergegeven per HGZO en HSAO Bachelor-opleiding.

\section{Figuur 2.4}

Vereist niveau en vereiste richting van de functie, 1998-2010

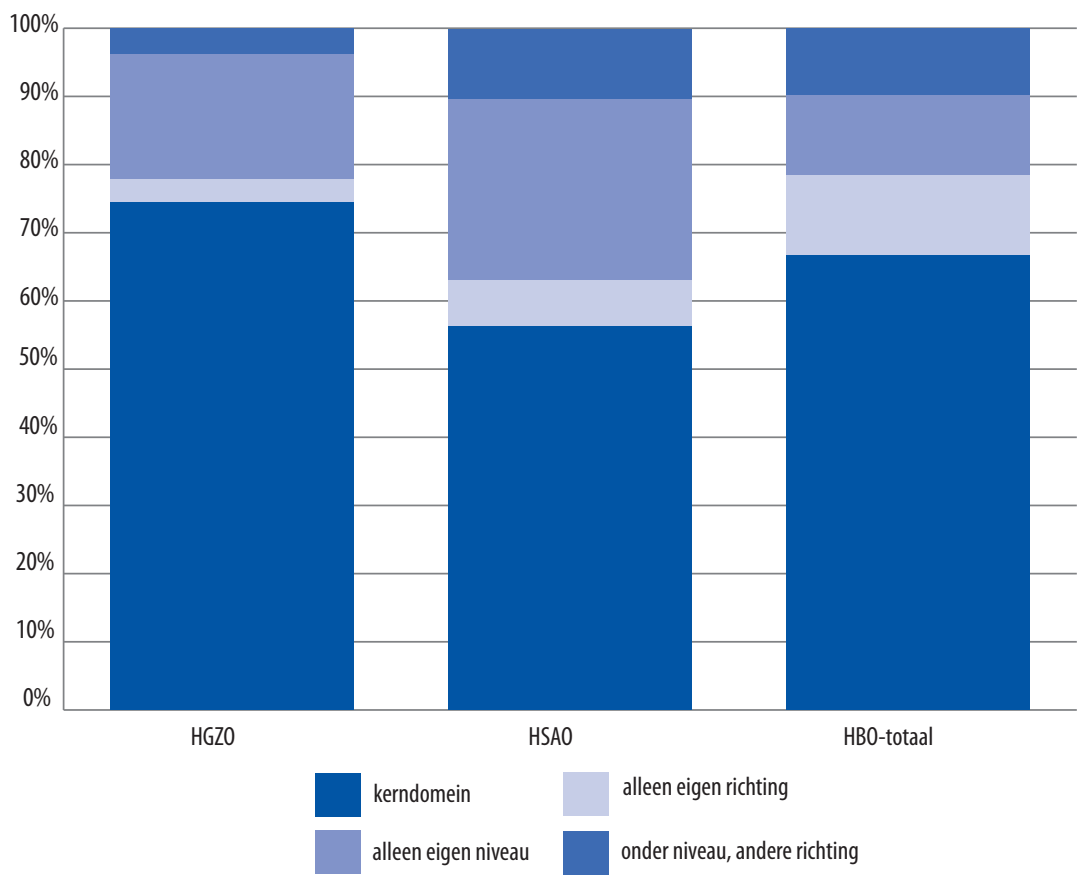

Bron: HBO-Monitor 1998-2010

Figuur 2.5 geeft aan hoe het percentage afgestudeerden dat binnen het kerndomein werkt verandert over de tijd. De figuur laat zien dat HGZO-verpleegkunde een prijs heeft betaald voor de hoge mate van werkzekerheid: het aandeel dat werkzaam is binnen het kerndomein is erg conjunctuurgevoelig, én structureel dalend, waardoor het aandeel van deze groep afgestudeerden die passend werk heeft in 20 Io duidelijk lager ligt dan het $\mathrm{HBO}$ gemiddelde. Dit percentage is voor de andere onderscheiden 
HGZO clusters hoger en redelijk stabiel in de tijd. HSAO toont over het algemeen een laag aandeel afgestudeerden dat werkzaam is binnen het kerndomein, maar vanaf 2006 lijkt de situatie iets beter te zijn geworden.

\section{Figuur 2.5}

Trend werkzaam in kerndomein (\%), 1998-2010

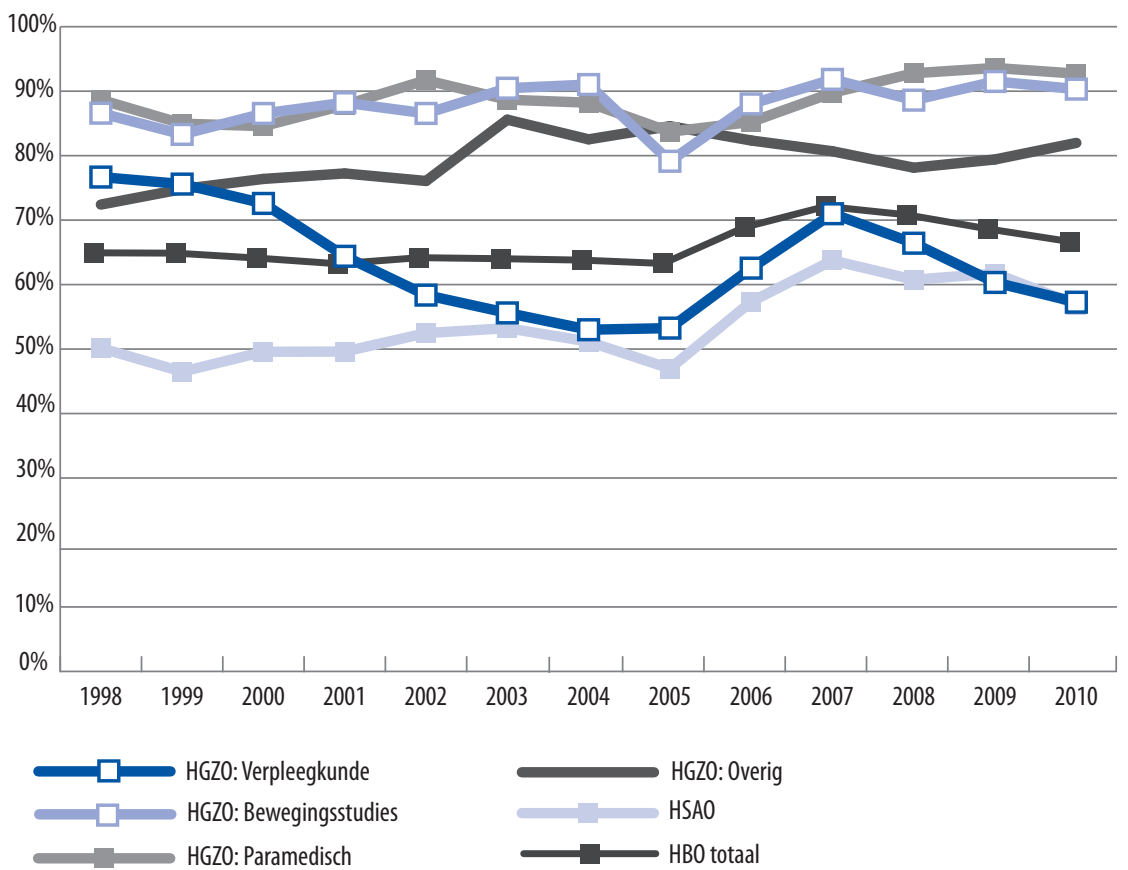

Bron: HBO-Monitor 1998-2010

\section{Aansluiting opleiding-werk}

Figuur 2.6 laat het percentage afgestudeerden zien dat de aansluiting tussen de gevolgde opleiding en de huidige functie goed of voldoende vindt. $\mathrm{Bij} \mathrm{HBO}$ als geheel is het oordeel over de aansluiting met name na 2002 aan het verslechteren. Dit is niet te verklaren door veranderingen in het aandeel werkenden binnen hun eigen kerndomein, aangezien dat percentage over de gehele periode vrijwel niet veranderd is (zie figuur 2.5). De verslechtering van de aansluiting tussen opleiding en werk geldt ook in zekere mate voor de verschillende clusters, zij het dat het absolute percentage sterk verschilt per cluster. De afgestudeerden van HGZO-paramedisch opleidingen en HGZO-bewegingsstudies zijn van de zorg- en welzijnsstudies het vaakst positief over de aansluiting, terwijl afgestudeerden van HGZO-verpleegkunde en HSAO het minst vaak een positief oordeel vellen. Dit laatste zou overigens wel kunnen samenhangen met het al dan niet werkzaam zijn binnen het kerndomein, aangezien HSAO en HGZO-Verpleegkunde tevens de zorg- en welzijnsstudies zijn waar men in de 
periode 1998-20Io het minst vaak binnen het kerndomein werkzaam is, en afgestudeerden van HGZO-Paramedisch en HGZO-Bewegingsstudies vlak na afstuderen juist het vaakst binnen hun kerndomein werken.

\section{Figuur 2.6}

Aansluiting opleiding-functie goed of voldoende, 1998-2010 (\%)

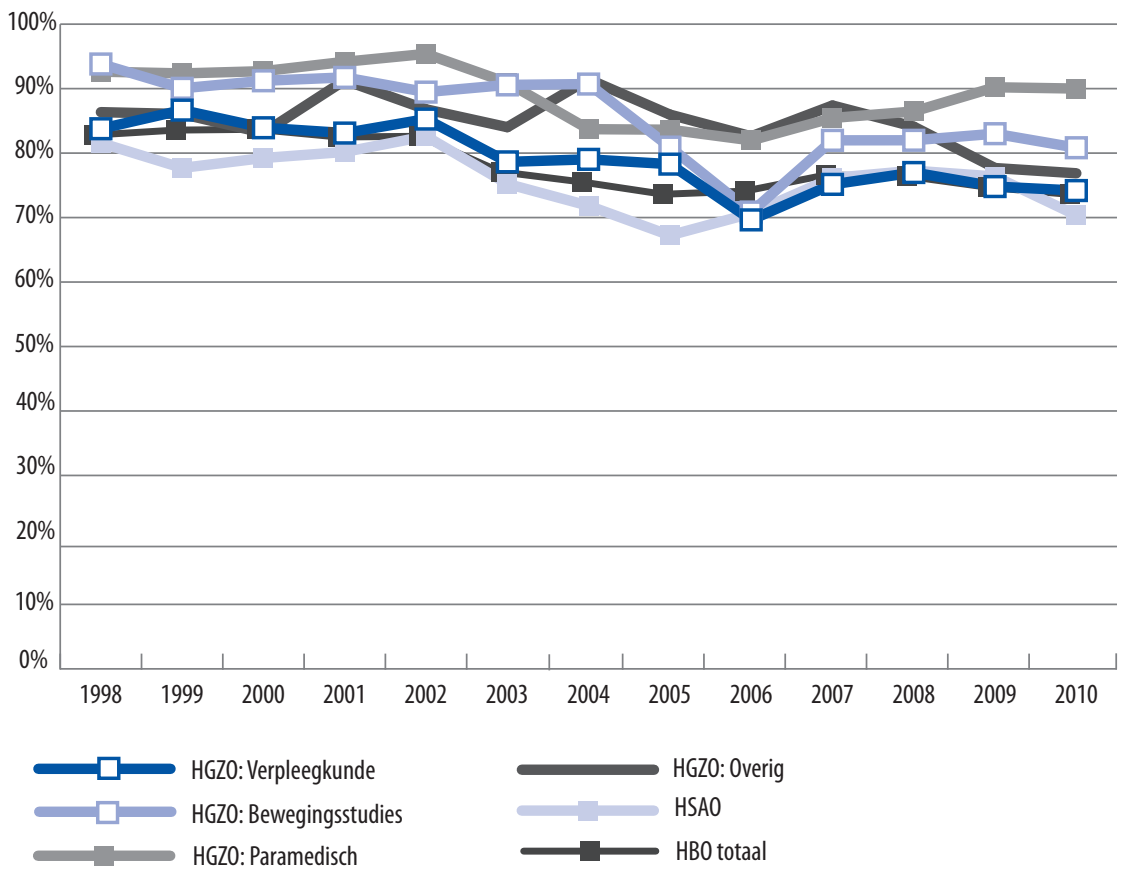

Bron: HBO-Monitor 1998-2010

\section{Inkomen huidige baan}

Figuur 2.7 laat de ontwikkeling in het reële bruto uurloon van afgestudeerden zien. Hoewel er wat conjuncturele fluctuaties zijn, is over de hele linie weinig structurele vooruitgang te zien in de lonen. De lonen voor afgestudeerden van het HSAO en HGZO-verpleegkunde zijn met name sinds 2006 verbeterd, en hebben hiermee hun lichte loonachterstand ten opzichte van het $\mathrm{HBO}$ gemiddelde weggewerkt. De lonen zijn veruit het hoogst onder afgestudeerden van HGZO-paramedische opleidingen. Zie bijlage 2 voor de gemiddelde bruto uurlonen per HGZO en HSAO Bacheloropleiding. 


\section{Figuur 2.7}

Reële² bruto uurloon huidige baan (euro), 1998-2010

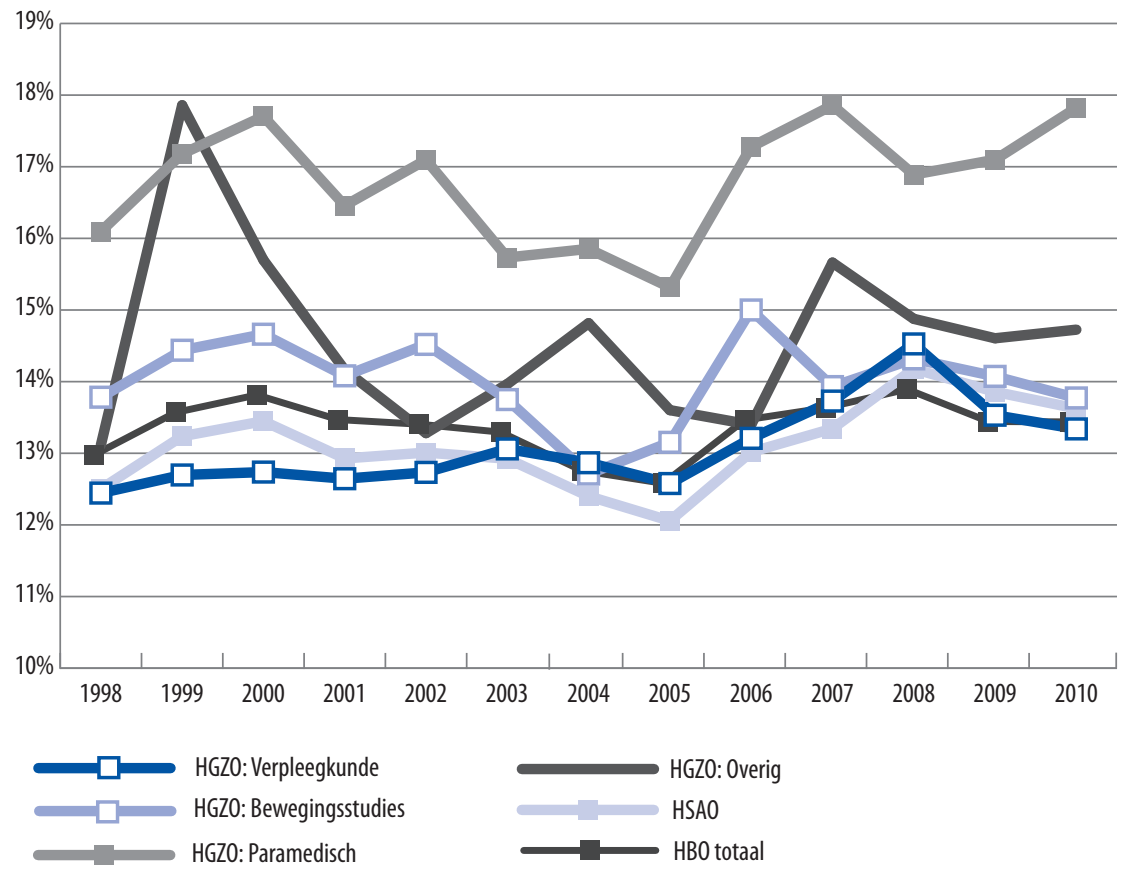

Bron: HBO-Monitor 1998-2010

\section{Tevredenheid met huidige baan}

Figuur 2.8 laat de trend in de baantevredenheid zien. Over de hele linie zijn afgestudeerden van de verschillende HGZO-clusters iets tevredener met hun werk dan HBO'ers als geheel, terwijl de tevredenheid onder HGZO'ers iets lager ligt dan het $\mathrm{HBO}$-gemiddelde. Zoals wellicht zou mogen worden verwacht is deze indicator tamelijk conjunctuurgevoelig, alleen bij HGZO-verpleegkunde geldt dit wat minder. De positie van HGZO-paramedische opleidingen is over de jaren sterk verbeterd. Zie bijlage 2 voor de tevredenheidspercentages per HGZO en HSAO Bachelor-opleiding.

2. Hierbij is gecorrigeerd voor de jaarlijkse inflatie zoals gemeten door het CBS. 


\section{Figuur 2.8}

(zeer) tevreden met huidige functie (\%), 2003-2010 3

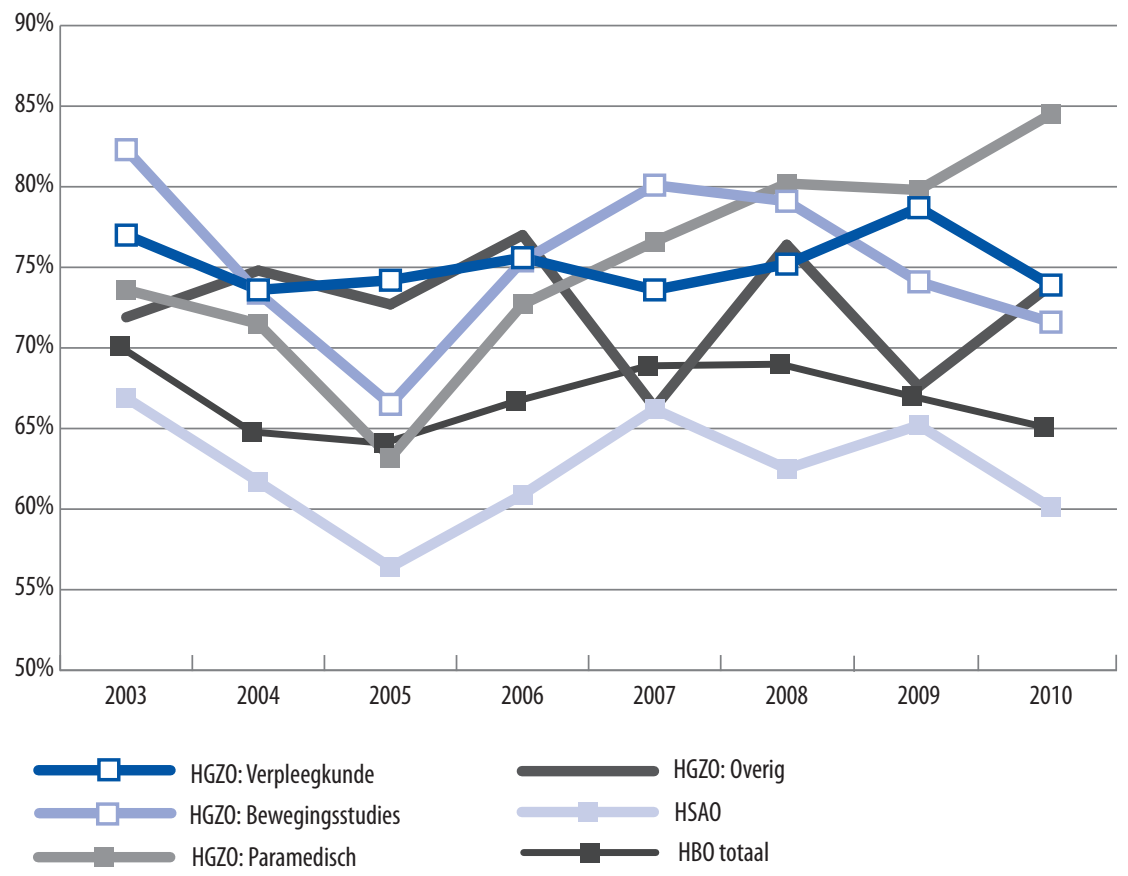

Bron: HBO-Monitor 2003-2010

3. De variabele tevredenheid met de huidige baan is niet beschikbaar voor eerdere jaren.

Enquêtevraag: Hoe tevreden bent u met uw huidige functie (I 'zeer ontevreden' tot en met 5 'zeer tevreden'. Vermeld is het percentage van antwoordcategorie 4 en 5 . 
Figuur 2.9

Spijt van de gekozen opleiding, 1998-2010 (\%)

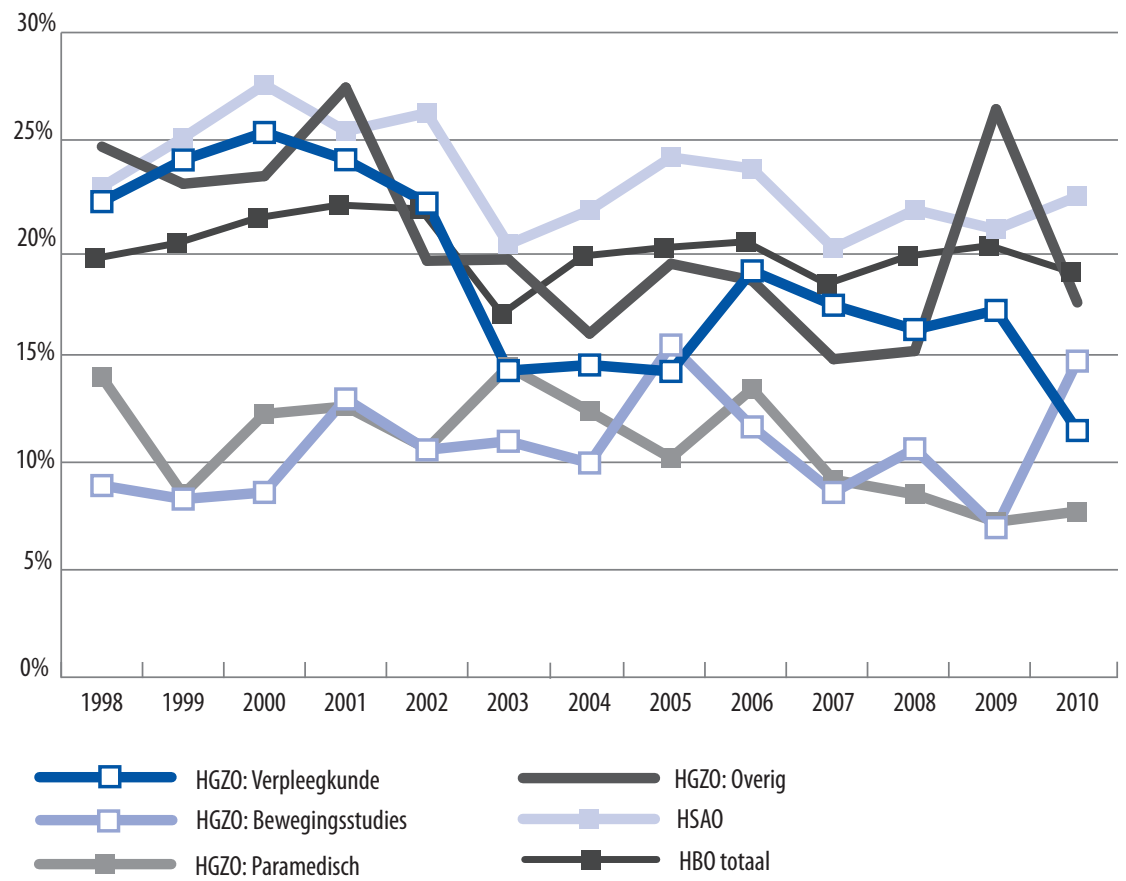

Bron: HBO-Monitor 1998-2010

\section{Spijt van de gekozen opleiding}

Figuur 2.9 laat het aandeel afgestudeerden zien dat aangeeft achteraf spijt te hebben van de opleidingskeuze, dat wil zeggen: als ze opnieuw zouden mogen kiezen zouden ze niet voor dezelfde opleiding kiezen. Voor de totale groep $\mathrm{HBO}$ afgestudeerden is dit percentage vrij stabiel in de tijd. Afgestudeerden van HSAO, HGZO-overig en vooral HGZO-verpleegkunde tonen in de loop van de jaren echter achteraf minder spijt van hun opleidingskeuze. Hiermee is HGZO-verpleegkunde veranderd van een van de clusters waar men het vaakst spijt had van de opleidingskeuze in het op één na meest tevreden cluster in dit opzicht. Ondanks de verbetering ligt het aandeel HSAO'ers dat spijt heeft van de opleiding in 2010 nog iets hoger dan het HBO-gemiddelde, maar het verschil is wel klein geworden. Zie de bijlage voor het percentage dat achteraf gezien spijt heeft van de gekozen opleiding, uitgesplitst naar HGZO en HSAO Bachelor-opleiding. 


\section{Cursus of bedrijfsopleiding gevolgd}

Tegenwoordig komt steeds meer nadruk te liggen op het belang van Leven Lang Leren, waarbij de continue ontwikkeling van menselijk kapitaal tijdens de loopbaan centraal staat. In dit kader is het ook interessant om te bekijken of starters op de arbeidsmarkt die een HGZO of HSAO opleiding hebben gevolgd zo kort na afstuderen al een cursus of bedrijfsopleiding van hun werkgever mochten volgen. Anders dan bij het $\mathrm{HBO}$ als geheel, waar de deelname aan bijscholing in de loop van de jaren licht is gedaald, is bij het HSAO en alle HGZO-clusters sprake van een duidelijke stijging in dit aandeel. Dit zou ermee te maken kunnen hebben dat het juist in de zorg- en welzijnssector van groot belang is dat alle medewerkers op de hoogte en kundig zijn op het gebied van nieuwe trends en ontwikkelingen in de sector. Te denken valt aan nieuwe apparatuur of BIG registratie.

\section{Figuur 2.10}

Deelname bijscholing, 1998-2010 (\%)

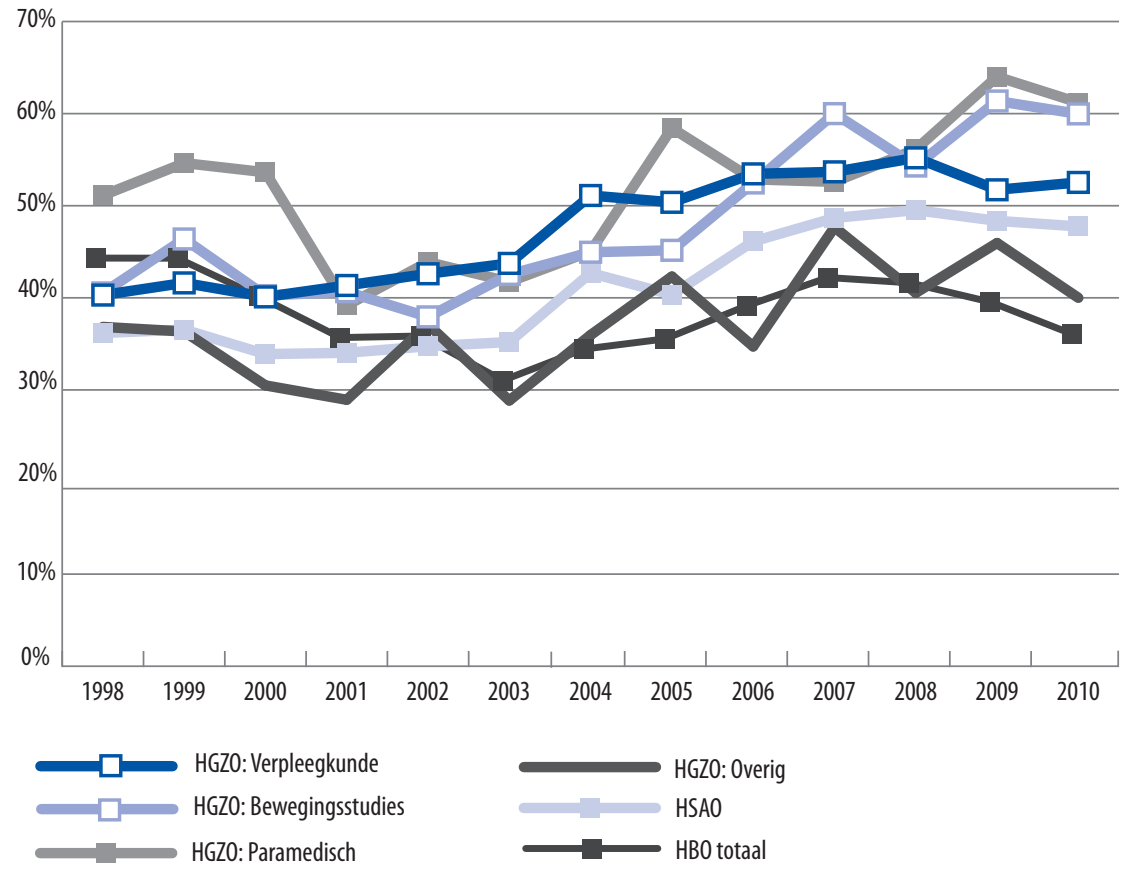

Bron: HBO-Monitor 1998-2010 



\section{Arbeidsmarktperspectieven}

In hoofdstuk 3 staan de verwachte arbeidsmarktperspectieven van 2009 tot 2014 voor HGZO en HSAO afgestudeerden centraal. Tweejaarlijks biedt ROA een overzicht van de huidige en toekomstige arbeidsmarktontwikkelingen. Een belangrijk onderdeel hierin zijn de arbeidsmarktperspectieven voor schoolverlaters. Het toekomstig arbeidsmarktperspectief geeft voor de verschillende opleidingstypen de verhouding weer tussen vraag en aanbod van schoolverlaters en afgestudeerden in de prognoseperiode. De vraag- en aanbodprognoses zijn gebaseerd op de arbeidsmarktpositie van een opleiding in 2009. Als het arbeidsmarktperspectief van een opleiding slecht is, betekent dit dat er de komende jaren veel meer aanbod van nieuwkomers zal zijn dan dat er baanopeningen zullen ontstaan. Hierdoor zal de arbeidsmarktpositie van deze afgestudeerden verslechteren. Deze verslechtering kan tot uiting komen in een hogere werkloosheid, maar door aanpassingsprocessen op de arbeidsmarkt kan de verslechtering van de arbeidsmarktsituatie ook leiden tot het moeten aanvaarden van banen op een lager niveau, tegen een lagere beloning of bijvoorbeeld een stijging van het aantal tijdelijke contracten. Omgekeerd zal een goed perspectief leiden tot een grotere kans op werk, maar ook tot een verbeterde positie op andere punten.

Het toekomst arbeidsmarktperspectief per opleidingstype wordt bepaald door middel van de Indicator Toekomstig Arbeidsmarktperspectief (ITA) 4 , die is gedefinieerd als de verhouding tussen enerzijds de verwachte arbeidsmarktinstroom van afgestudeerden en het aantal kortdurig werklozen en anderzijds de verwachte baanopeningen en de passieve substitutievraag. ${ }^{5}$ Naarmate de waarde van de indicator hoger is, wordt het perspectief slechter. De bijbehorende kwalitatieve typering van de arbeidsmarktperspectieven luist respectievelijk zeer goed, goed, redelijk, matig of slecht. Daarnaast wordt ook de Indicator Toekomstige Knelpunten Personeelsvoorziening (ITKP) weerge-

4. Zie voor meer informatie over de arbeidsmarktperspectieven van schoolverlaters: ROA (2009), De arbeidsmarkt naar opleiding en beroep tot 2014, Maastricht: Researchcentrum voor Onderwijs en Arbeidsmarkt.

5. Als gevolg van discrepanties tussen vraag en aanbod op de arbeidsmarkt treden er verschuivingen op in de werkgelegenheidsstructuur. Schoolverlaters in een aanbodoverschotsituatie kunnen anders opgeleiden gaan verdringen, terwijl werkgevers die te kampen hebben met een tekortschietend arbeidsaanbod, personen met een andere opleidingsachtergrond kunnen gaan werven. De vraag die hierdoor verloren gaat of ontstaat wordt aangeduid als het passieve substitutie-effect. Als het passieve substitutie-effect positief is, gaat het om extra baanopeningen als gevolg van tekorten bij andere opleidingen. Een negatief substitutie-effect duidt daarentegen op een verlies aan baanopeningen, omdat men verdrongen wordt door andere opleidingen. 
geven, die aangeeft in hoeverre er personeelstekorten worden verwacht bij werkgevers in de verschillende sectoren. Door deze definiëring is het de verwachting dat hoe groter het verwachte personeelstekort in een sector is, hoe beter de verwachte arbeidsmarktperspectieven zijn. Tabel 3.I toont de arbeidsmarktperspectieven en toekomstige knelpunten personeelsvoorziening tot 2014 voor afgestudeerden van het $\mathrm{HGZO}$ en HSAO. ${ }^{6} \mathrm{Om}$ de cijfers wat meer diepgang te geven, zijn ook de prognoses voor schoolverlaters van het $\mathrm{MBO}$ gezondheidszorg, $\mathrm{MBO}$ gedrag \& maatschappij en afgestudeerden van het universitaire gezondheidszorgonderwijs opgenomen.

Tabel 3.1

Indicator Toekomstige Arbeidsmarktperspectieven (ITA) en Indicator Toekomstige Knelpunten Personeelsvoorzieningen (ITKP) voor zorg- en welzijnsstudies tot 2014, per opleidingsniveau en -type.

\begin{tabular}{|c|c|c|c|c|c|}
\hline \multirow{2}{*}{\multicolumn{2}{|c|}{ Opleidingstype }} & \multicolumn{2}{|r|}{ ITA } & \multicolumn{2}{|r|}{ ITKP } \\
\hline & & Indicator & Typering & Indicator & Typering \\
\hline \multicolumn{6}{|l|}{ MBO } \\
\hline \multicolumn{2}{|c|}{ MBO dokters-, tandarts- en dierenartsassistent } & 0,93 & Goed & 0,93 & Groot \\
\hline \multicolumn{2}{|c|}{ MBO apothekersassistent } & 0,88 & Goed & 0,88 & Groot \\
\hline \multicolumn{2}{|c|}{ MBO verpleging } & 0,97 & Goed & 0,97 & Groot \\
\hline \multicolumn{2}{|c|}{ MBO gezondheidstechniek } & 1,26 & Slecht & 1,26 & Geen \\
\hline \multicolumn{2}{|c|}{ MB0 sociaal-pedagogisch en welzijn } & 1,17 & Slecht & 1,18 & Geen \\
\hline \multicolumn{2}{|c|}{ MBO verzorging } & 1,01 & redelijk & 1,01 & Enige \\
\hline \multicolumn{2}{|c|}{ MBO beweging en therapie } & 1,14 & Matig & 1,14 & Vrijwel geen \\
\hline \multicolumn{6}{|c|}{ HGZO } \\
\hline \multicolumn{2}{|c|}{ HBO verpleegkunde } & 0,78 & Zeer goed & 0,78 & Zeer groot \\
\hline \multicolumn{2}{|c|}{ HBO (fysio)therapie } & 0,98 & Goed & 0,98 & Groot \\
\hline \multicolumn{2}{|c|}{ HBO voeding } & 1,03 & Redelijk & 1,04 & Enige \\
\hline \multicolumn{2}{|c|}{ HBO radiologie } & 0,82 & Zeer goed & 0,82 & Zeer groot \\
\hline \multicolumn{6}{|c|}{ HSAO } \\
\hline \multicolumn{2}{|c|}{ HBO maatschappelijk werk en hulpverlening } & 1,02 & Redelijk & 1,04 & Enige \\
\hline \multicolumn{2}{|c|}{$\mathrm{HBO}$ pedagogie } & 0,99 & Goed & 0,99 & Groot \\
\hline \multicolumn{6}{|l|}{ wo } \\
\hline \multicolumn{2}{|c|}{ WO (dier)geneeskunde } & 0,97 & Goed & 0,97 & Groot \\
\hline \multicolumn{2}{|c|}{ WO tandheelkunde } & 0,75 & Zeer goed & 0,75 & Zeer groot \\
\hline \multicolumn{2}{|c|}{ WO farmacie en medische biologie } & 0,85 & Zeer goed & 0,85 & Zeer groot \\
\hline \multicolumn{2}{|c|}{$\begin{array}{ll}\text { Bron: } & \text { ROA (AIS) } \\
\text { ITA } & \text { Indicator Toekomstige Arbeidsmarktsituatie in 2014 } \\
\text { ITKP } & \text { Indicator Toekomstige Knelpunten Personeelsvoorziening in } 2014\end{array}$} & & & & \\
\hline
\end{tabular}

6. NB: de prognoses gaan uit van een iets andere opleidingsindeling dan dat wordt gehanteerd in de HBO-Monitor. 
In de tabel is te zien dat de arbeidsmarktperspectieven voor afgestudeerden van opleidingen in de gezondheidszorg tot 2014 doorgaans goed zijn, ongeacht het opleidingsniveau. De verwachte knel-punten in de personeelsvoorziening zijn in de gezondheidszorg dan ook doorgaans (zeer) groot, wat betekent dat het personeelstekort in deze sector naar verwachting zal toenemen. Van de HGZO oplei-dingen zijn met name de arbeidsmarktperspectieven voor afgestudeerden van $\mathrm{HBO}$ verpleegkunde en $\mathrm{HBO}$ radiologie zeer goed te noemen. De arbeidsmarktperspectieven tot 2014 voor afgestudeerden van de sociaal-agogische opleidingen zijn zowel voor het $\mathrm{MBO}$ als het $\mathrm{HBO}$ (veel) minder positief, hoewel de perspectieven voor $\mathrm{HBO}$ pedagogie met een ITA van 0,99 nog steeds goed te noemen zijn. 



\section{Vereiste competenties voor afgestudeerden van het HGZO en HSAO}

In hoofdstuk 2 werd een korte schets gegeven van de arbeidsmarkt voor afgestudeerden van het HGZO en HSAO in het verleden en het heden, en in hoofdstuk 3 werden prognoses gepresenteerd van de verwachte ontwikkelingen van de werkgelegenheid in de toekomst. Deze vooral kwantitatieve ontwikkelingen zijn interessant en belangrijk, maar zeggen weinig of niets over hoe het werk in de toekomst in kwalitatieve zin eruit zal zien. In dit hoofdstuk komt aan bod welke trends en ontwikkelingen zich voordoen in de sector en hoe het onderwijsveld op de te verwachten trends kan inspelen bij het opleiden van toekomstige arbeidskrachten voor de zorg- en welzijnssector. De focus ligt hierbij op de competenties waar het onderwijsveld zich op moet gaan richten. In paragraaf 4.I worden allereerst enkele algemene en sectorspecifieke trends aangestipt. In paragraaf 4.2 komt het vereiste competentieniveau aan bod van recent afgestudeerden die werkzaam zijn in hun kerndomein. Bovendien wordt hier besproken of bepaalde competenties door de jaren heen belangrijker zijn geworden. In paragraaf 4.3 komen vervolgens de ervaren competentietekorten aan bod.

\subsection{Trends en ontwikkelingen}

Voorbeelden van algemene sector overstijgende trends zijn onder meer demografische ontwikkelingen zoals vergrijzing en ontgroening, voortschrijdende technologische ontwikkelingen, de toenemende invloed van internet en ICT, heterogeniteit van de samenleving, individualisering van mondialisering, klimaatproblematiek en de verschuiving van het economisch zwaartepunt en de daarmee gepaard gaande internationale machtsverhoudingen. Deze raken alle in meer of mindere mate de gehele zorg-en welzijnssector.

$\mathrm{Al}$ deze trends kunnen op hun beurt vragen om specifieke competenties van de arbeidskrachten die werkzaam zijn in een sector, en dus indirect van invloed zijn op de inrichting van het Hoger Onderwijs. Deze ontwikkelingen leiden er immers toe dat bepaalde competenties belangrijker worden, terwijl andere competenties in de toekomst mogelijkerwijs juist minder van afgestudeerden gevraagd zullen worden.

Op basis van de literatuur kunnen er vier trends worden gedefinieerd die specifiek spelen in de zorg- en welzijnssector: een groeiende zorgvraag, sectorspecifieke tech- 
nologische ontwikkelingen, veranderende organisatie van de zorg, en veranderend aanbod van zorgwerkers. Hieronder worden deze trends kort toegelicht.

\section{Groeiende zorgvraag}

Naar verwachting zal de vraag naar zorg in de toekomst sterk toenemen. Op demografisch gebied krijgen we de komende jaren te maken met een ontgroening en dubbele vergrijzing: niet alleen het aantal ouderen neemt toe en komen er minder jongeren bij, maar de ouderen worden ook steeds ouder. Aangezien ouderen relatief een hogere zorgvraag hebben dan jongeren, leidt dit tot een groeiende zorgvraag. Te denken valt aan een toename van chronische ziektes als COPD, diabetes mellitus en hartfalen. Daar komt bij dat over de gehele linie (zowel onder ouderen als jongeren) patiënten steeds mondiger worden. Over het algemeen wordt aangenomen dat dat meer werk voor hulpverleners betekent (Ministerie van VWS, 2007, pio5).

\section{Sectorspecifieke technologische ontwikkelingen}

Een algemene ontwikkeling die niet alleen geldt voor de sectoren zorg en welzijn maar voor alle sectoren van de arbeidsmarkt, is de toenemende rol van techniek in het werk. Dankzij technologische en geautomatiseerde vernieuwingen is het mogelijk om aangepaste woningen te bouwen, geavanceerde zorg te bieden en mensen met een beperking te ondersteunen in hun dagelijks leven (Dekker e.a., 2002). Door de steeds verdergaande toename van medische kennis en technologie, samen met het toenemende opleidingsniveau van de bevolking, zal de levensverwachting verder toenemen (wat leidt tot de groeiende zorgvraag). De toename van complexere medische technologie in ziekenhuizen vereist wel dat niet alleen ziekenhuizen, zorginstellingen, instituten en fabrikanten, maar ook wetenschappers, artsen/medische specialisten, fysici en technici van universiteiten, fabrikanten en zorginstellingen intensiever en structureler samenwerken. Te verwachten valt dat ICT competenties, alsook vaardigheden om samen te werken met andere instellingen en instituten en met collega's met een andere disciplinaire achtergrond en onderzoeksvaardigheden derhalve belangrijker zullen worden voor het werk van afgestudeerden.

\section{Veranderende organisatie van de zorg}

De zorg wordt in toenemende mate geprivatiseerd. Door de marktwerking in de sector zorg en welzijn wordt het leveren van diensten steeds meer beschouwd als een productieproces waarin professionele organisaties en professionals input leveren en afgerekend worden op hun output. Om de kwaliteit van de geboden diensten te meten en verbeteren wordt er steeds meer met protocollen en standaardformulieren gewerkt. De toenemende verzakelijking leidt ook tot een verregaande opdeling in functies en verantwoordelijkheden (van der Laan et al, 2003). Dit heeft mogelijke consequenties voor de grenzen tussen $\mathrm{HBO}$ functies in de zorg en functies op andere niveaus, met name op MBO-niveau (van Vliet et al, 2004, p20). Verzakelijking en 
toenemende marktwerking beperken ook de handelingsruimte van professionals in de sector. Deze handelingsruimte wordt enerzijds beperkt door de noodzaak van doelmatigheid en protocollering, en anderzijds door de vraag van cliënten, zorgverzekeraars en financiers (van Vliet et al, 2004, p22; Scherpbier et al, 2010, p6). Daarnaast is er sprake van extramuralisering van de zorg, wat inhoudt dat het aantal gebruikers van thuiszorg de komende decennia zal stijgen en het aantal mensen dat in verzorgings- of verpleegtehuizen verblijft zal dalen (Ministerie van VWS, 2007, p49).

\section{Feminisering van het artsenberoep}

Studenten geneeskunde en specialisten in opleiding zijn in toenemende mate jonge vrouwen (Scherpbier et al, 20I0). Deze vrouwelijke medici werken vaker dan hun mannelijke collega's in deeltijd functies. Dit wordt duidelijk cijfermatig geïllustreerd door de Vereniging van Vrouwelijke Artsen (20IO). Als gevolg van het door de feminisering van het artsenberoep toenemende aandeel artsen dat in deeltijd werkt, dreigt er een tekort aan universitair geschoolde medici. Daardoor ontstaat er ruimte voor HBO-masteropleidingen zoals de Master Advanced Nurcing Practice en de Master Physician Assistant. De taken van deze zorgwerkers bestaan vooral uit medische en verpleegkundige handelingen die voorheen werden uitgevoerd door artsen en medisch specialisten.

\subsection{Vereist niveau competenties}

Gebruikmakend van gegevens uit de HBO-Monitor wordt in deze paragraaf ingegaan op het competentieniveau dat vereist is voor afgestudeerden van het HGZO en HSAO die in hun kerndomein (aansluiting opleiding-werk naar zowel opleidingsniveau als opleidingsrichting) werkzaam zijn. Tabel 4.I toont het aandeel van de afgestudeerden die hebben aangegeven dat de desbetreffende competentie op een hoog niveau is vereist (antwoord 4 of 5 op een 5-puntschaal die loopt van I 'matig niveau vereist' $\mathrm{t} / \mathrm{m} 5$ 'uitmuntend niveau vereist'). Om een beeld te krijgen van de mate waarin de competentievereisten aan het veranderen zijn, wordt tevens de trend in deze vereisten berekend, m.a.w. de gemiddelde toe- of afname per jaar. De trend wordt alleen getoond wanneer deze statistisch significant is. 

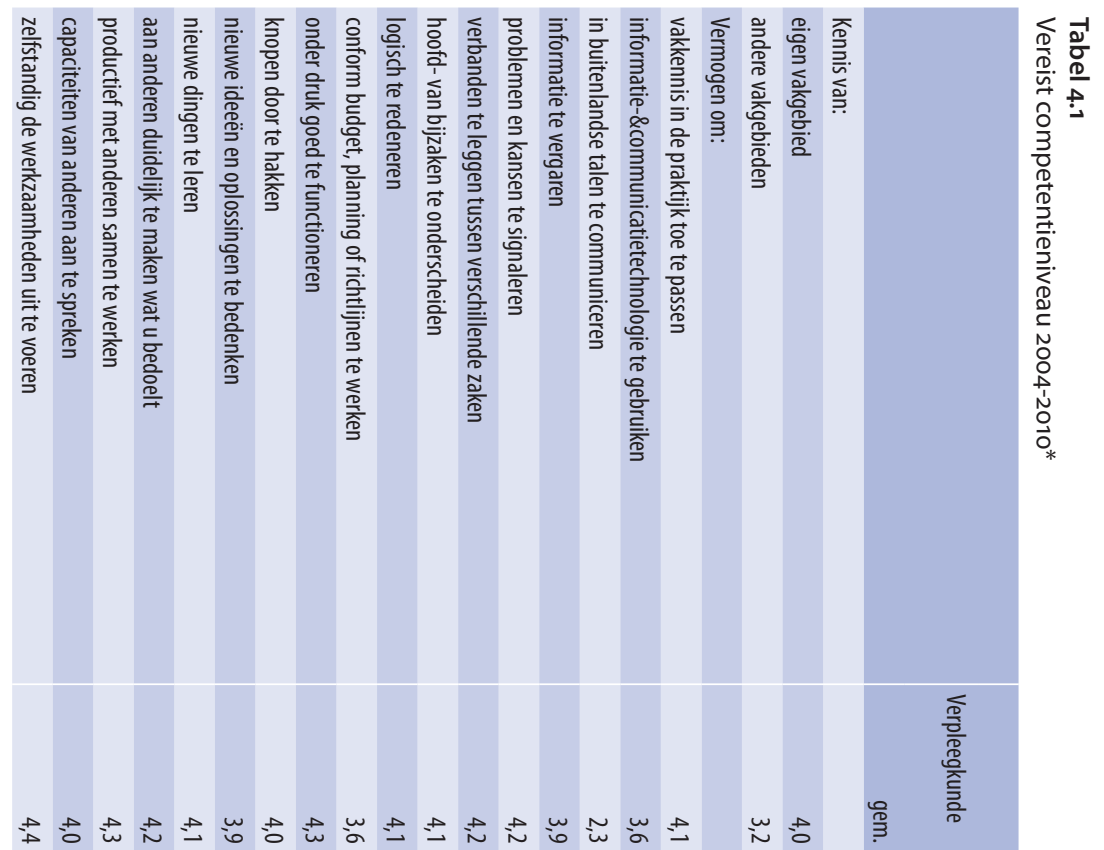

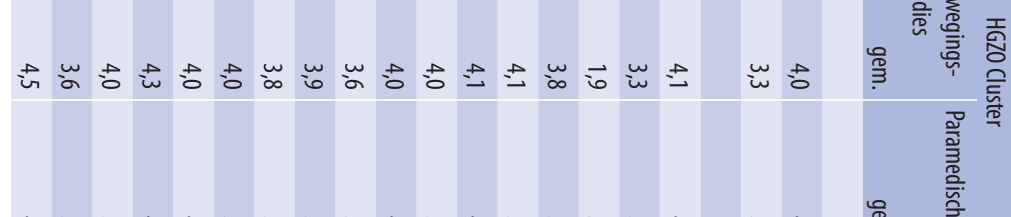

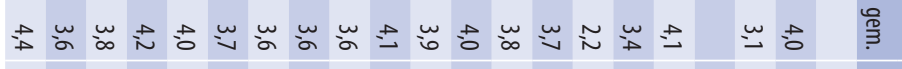

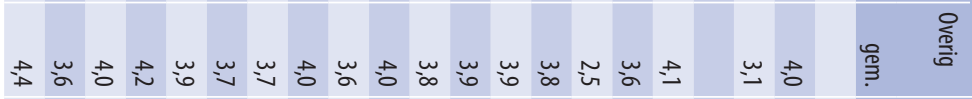

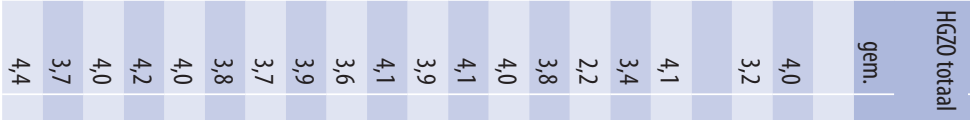

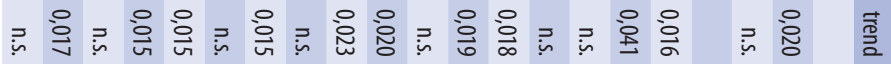

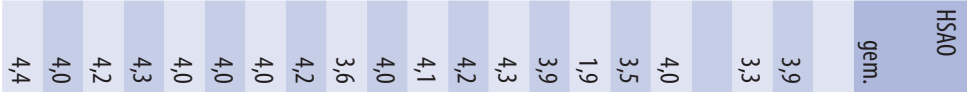

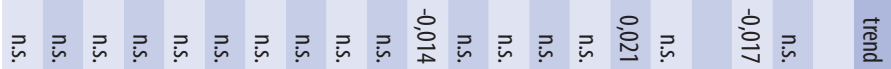

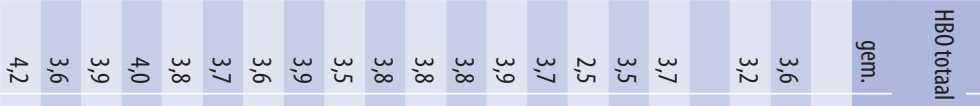

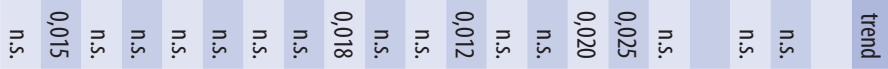




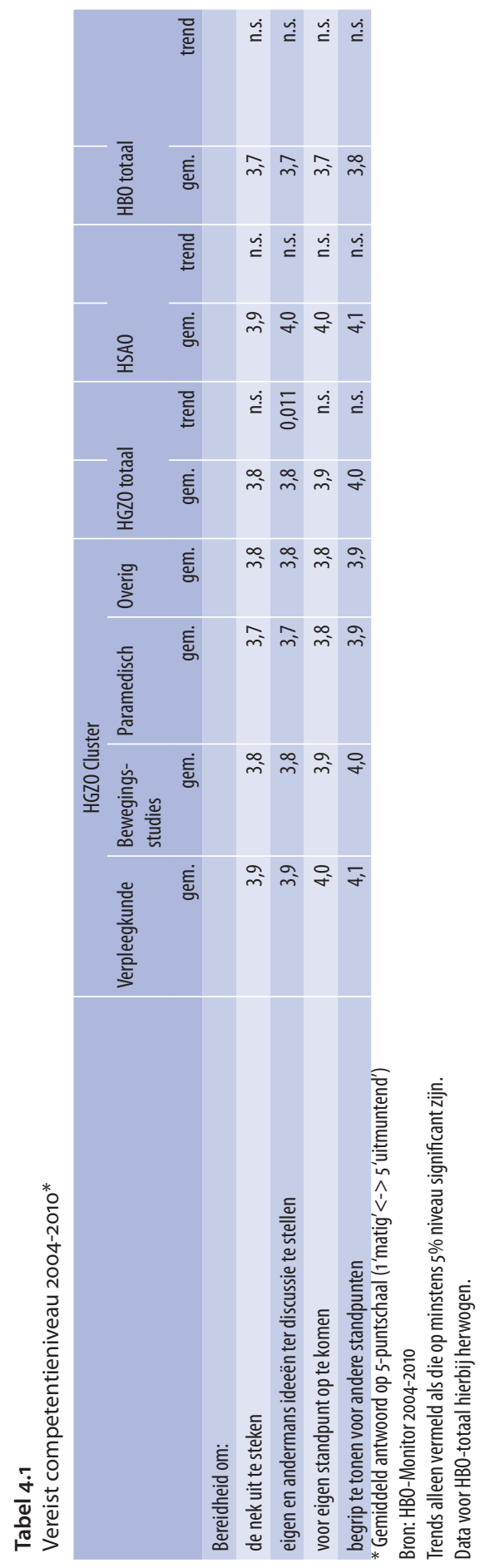


Opvallend is dat over de hele linie de competentievereisten hoger liggen voor afgestudeerden van het $\mathrm{HGZO}$ en het $\mathrm{HSAO}$ dan voor $\mathrm{HBO}$-afgestudeerden in het algemeen. De enige uitzondering hierop wordt gevormd door het vermogen om in buitenlandse talen te communiceren, dat met name bij HGZO-bewegingsstudies en $\mathrm{HSAO}$ beduidend lager ligt dan bij het $\mathrm{HBO}$ als geheel. Het vereiste niveau van vakkennis, evenals het vermogen om vakkennis in de praktijk toe te passen, ligt beduidend hoger bij zowel het HGZO als het HSAO dan bij het $\mathrm{HBO}$ als geheel. Wat betreft meer generieke competenties, ligt vooral bij het HSAO het vereiste niveau bij veel van deze competenties merkbaar hoger dan bij het $\mathrm{HBO}$ als geheel. Dit geldt voor analytische competenties (vermogen om problemen en kansen te signaleren, om verbanden te leggen tussen verschillende zaken, en om hoofd- van bijzaken te onderscheiden), procedurele competenties (vermogen om onder druk goed te functioneren en om knopen door te hakken), innovatiecompetenties (vermogen om nieuwe ideeën en oplossingen te bedenken), sociaal-communicatieve competenties (vermogen om aan anderen duidelijk te maken wat $\mathrm{u}$ bedoelt, om productief met anderen samen te werken en om capaciteiten van anderen aan te spreken), evenals een aantal houdingsaspecten (bereidheid om eigen en andermans ideeën ter discussie te stellen, om voor eigen standpunt op te komen, en om begrip te tonen voor andere standpunten). Bij het HGZO zijn behalve vakkennis vooral een aantal analytische competenties (vermogen om verbanden te leggen tussen verschillende zaken en om logisch te redeneren) vaak op relatief hoog niveau vereist, vooral bij HGZO-gezondheidszorg. Afgestudeerden van deze cluster worden ook vaak geacht competenties te bezitten op het gebied van daadkracht (vermogen om knopen door te hakken en om onder druk goed te functioneren) en samenwerken/leidinggeven (vermogen om productief met anderen samen te werken en om capaciteiten van andere aan te spreken).

Hoewel de gemiddelde competentievereisten iets hoger liggen bij het HSAO dan bij het HGZO, (tenminste wat betreft generieke competenties), zijn de meeste veranderingen in de competentievereisten te zien bij het HGZO. ${ }^{7} \mathrm{Bij}$ meer dan de helft van alle competenties is sprake van een significante toename tussen 2004 en 2010 in het gemiddeld niveau dat wordt vereist. Dit geldt voor vakkennis (kennis van eigen vakgebied en vermogen om vakkennis in de praktijk toe te passen), ICT-vaardigheden, analytische vaardigheden (vermogen om problemen en kansen te signaleren, om verbanden te leggen tussen verschillende zaken en om logisch te redeneren), procedurele vaardigheden (vermogen om conform budget, planning of richtlijnen te werken en om knopen door te hakken), leervaardigheden (vermogen om nieuwe dingen te leren), sociaal-communicatieve vaardigheden (vermogen om aan anderen duidelijk te maken wat $\mathrm{u}$ bedoelt en om capaciteiten van anderen aan te spreken) en houdingsaspecten (bereidheid om eigen en andermans ideeën ter discussie te stellen). Veel van deze trends liggen in de lijn der verwachting gezien de besproken ontwikkelingen in de zorgsector. Bij het HSAO zijn alleen ICT-vaardigheden belangrijker geworden.

7. Vanwege databeperkingen was niet mogelijk om deze trends betrouwbaar te schatten voor de onderliggende clusters bij HGZO. 
Opvallend is dat bij het HSAO de kennis van andere vakgebieden, evenals het vermogen om hoofd- van bijzaken te onderscheiden, minder belangrijk lijken te zijn geworden over tijd.

Voor een deel zijn deze veranderingen in competentievereisten consistent met wat op basis van de beschreven ontwikkelingen werd verwacht. ICT competenties worden inderdaad belangrijker voor het werk van afgestudeerden. De toename van protocollen, standaardformulieren e.d. waarmee men te maken krijgt heeft tevens zoals verwacht geresulteerd in een stijging in het belang van procedurele vaardigheden. Tegen de verwachting heeft de toenemende noodzaak van samenwerking binnen en tussen instellingen niet geresulteerd in het belangrijker worden van samenwerkingsvaardigheden en interdisciplinaire kennis. Sterker nog: onder afgestudeerden HSAO'ers is het gemiddeld vereiste niveau van interdisciplinaire kennis juist gedaald. Wel zijn communicatieve vaardigheden belangrijker geworden onder HGZO'ers. Ondanks het toegenomen risico van beknelling tussen de eisen van enerzijds zorgclienten en anderzijds zakelijke managers is er geen verandering te zien in het vereiste niveau van het vermogen om met druk om te kunnen gaan. In een aantal van deze gevallen kan het uitblijven van een stijging in het belang van bepaalde competenties aan plafond effecten liggen. Met name bij samenwerkingsvaardigheden en het vermogen om onder druk goed te functioneren ligt het gemiddeld vereiste niveau al tamelijk hoog, waardoor er weinig ruimte meer is voor stijging.

\subsection{Competentietekorten}

De vraag is hoe het onderwijs op het verschuivend belang van competenties heeft gereageerd. Heeft het toenemende belang van veel competenties met name bij het HGZO geresulteerd in tekorten voor de betreffende competenties, of heeft het onderwijs deze ontwikkeling weten bij te benen door het niveau van deze competenties bij afgestudeerden op te krikken? Zijn er los van de besproken trends in het vereiste niveau ook competenties waarbij sprake is van een meer structureel tekort? Hiervan geeft tabel 4.2 een beeld. Deze toont de ervaren competentietekorten door afgestudeerden die in hun kerndomein werkzaam zijn. Omdat in de HBO-Monitor zowel het vereiste competentieniveau als het eigen competentieniveau op eenzelfde 5 -puntschaal (I'matig' <-> 5 'uitmuntend') is gemeten, geeft de verschilscore voor iedere competentie een indicatie van een eventueel tekort of overschot. Van een competentietekort is sprake wanneer het vereiste niveau hoger is dan het eigen niveau. Het is belangrijk om op te merken dat een tekort niet noodzakelijkerwijs negatief hoeft te zijn. Wanneer er namelijk sprake is van een klein tekort wordt dit vaak ervaren als een uitdaging om dit punt te verbeteren. Wanneer afgestudeerden met betrekking tot een bepaalde competentie het gevoel hebben dat zij al een bepaald niveau bereikt hebben, zouden zij wel eens gemakzuchtig kunnen worden en geen noodzaak zien om zich te blijven ontwikkelen op dat punt. Wel kan er een signaalfunctie van deze tekorten uitgaan. Net als bij het vereiste niveau wordt tevens de trend in tekorten berekend, 
m.a.w. de gemiddelde toe- of afname per jaar. De trend wordt alleen getoond wanneer deze statistisch significant is.

De toename bij het HGZO in het belang van vakkennis en het vermogen om deze kennis in de praktijk toe te passen heeft niet geleid tot een toename in het percentage met een tekort aan deze competenties. Dat neemt niet weg dat er sprake is van een structureel hoog tot zeer hoog tekort aan deze competenties. Bijna de helft (47\%) van de HGZO'ers geeft aan dat ze een minder hoog niveau van vakkennis hebben dan is vereist in hun werk, en ruim een derde (35\%) dat dit het geval is voor het vermogen om vakkennis in de praktijk toe te passen. Bij het HSAO liggen deze percentages dicht bij de landelijke gemiddelden voor het $\mathrm{HBO}$ als geheel, die overigens ook zeer hoog te noemen zijn.

De toename in het vereiste niveau van generieke competenties bij HGZO'ers heeft in veel gevallen wel geleid tot een toename in het percentage met een tekort aan de betreffende competenties. Alleen in het geval van het vermogen om knopen door te hakken en om capaciteiten van anderen aan te spreken heeft een toename in het vereiste niveau niet geleid tot een toename in het percentage dat een tekort heeft. Hoewel zowel voor afgestudeerden van het HGZO als het HSAO het vereiste niveau van de competentie 'vermogen om informatie en communicatietechnologie te gebruiken' significant stijgt, en er door de HGZO afgestudeerden een significant groter wordend tekort wordt ervaren op deze competentie, betreft het hier slechts I2\% van de HGZO afgestudeerden dat werkelijk een tekort op deze competentie ervaart. Dit geeft aan dat het groeiende tekort (nog) geen grootschalig probleem is, maar dat er wel tijdig moet worden ingegrepen om verder groei van het tekort te voorkomen. Interessant genoeg toont een aantal competenties een toenemend percentage met een tekort onder HGZO'ers, terwijl geen sprake is van een toename in het vereiste niveau. Dit geldt voor het vermogen om informatie te vergaren en om productief met anderen samen te werken. Bij het HSAO toont de ontwikkeling van tekorten helemaal geen verband met de ontwikkeling van het vereiste niveau. Er is geen corresponderende verandering in tekorten als gevolg van de waargenomen verandering in het vereiste niveau van een drietal competenties, maar wel een toename in het percentage met een tekort aan het vermogen om in buitenlandse talen te communiceren en om knopen door te hakken. 


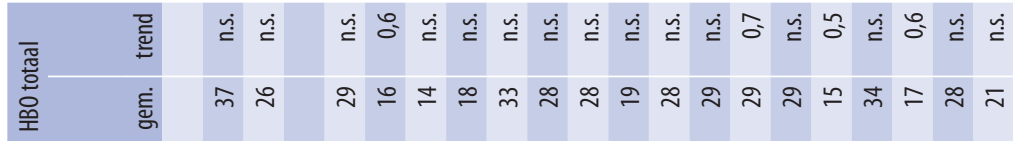

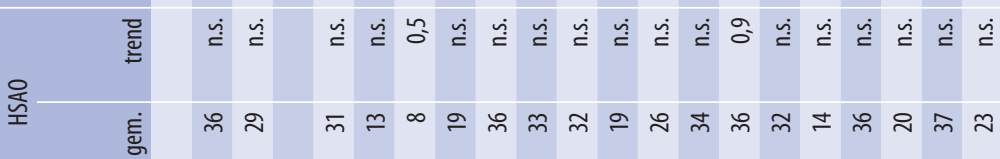

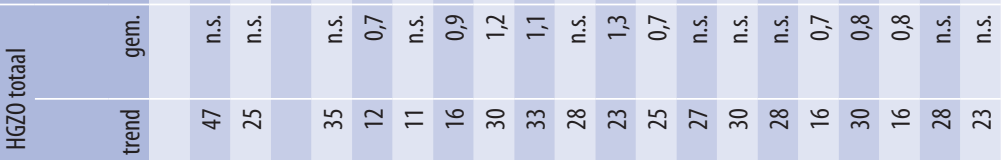

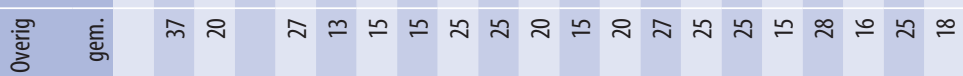

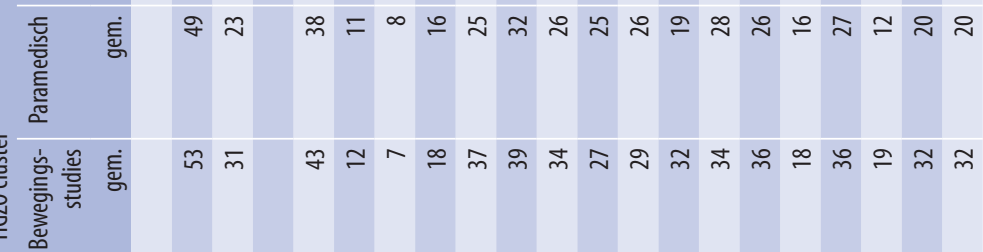

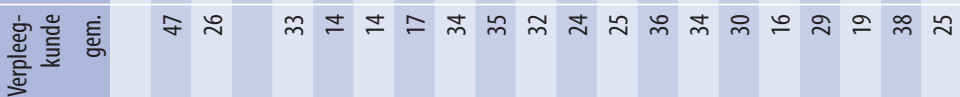

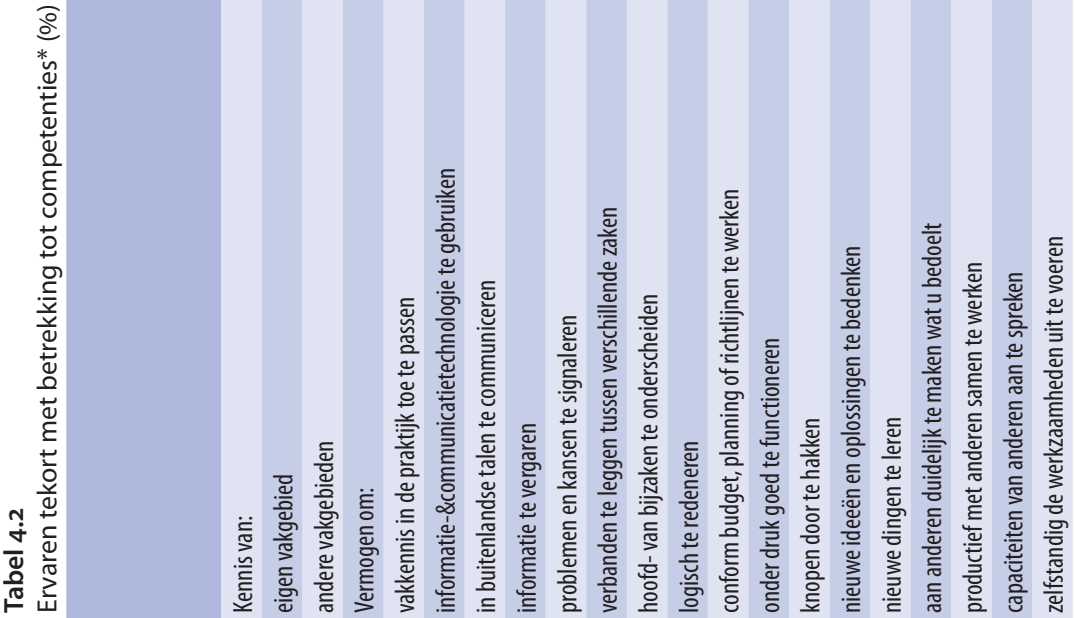


HOOFDSTUK 4
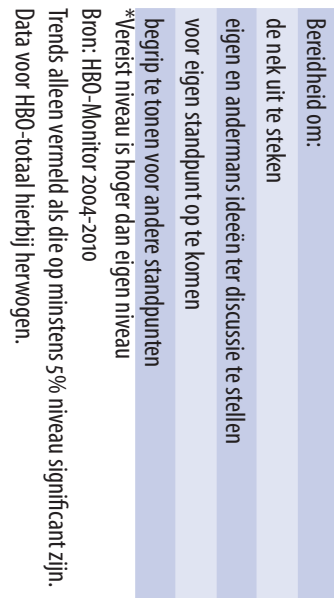

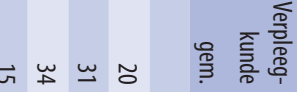
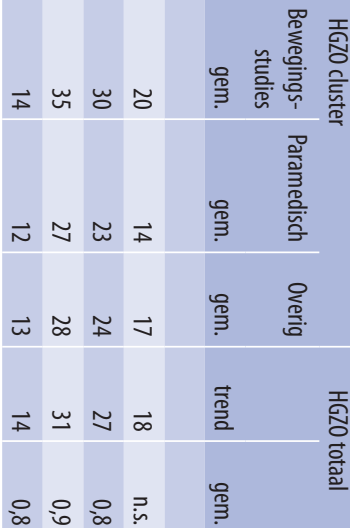

$\vec{్} \tilde{\sim} \tilde{\circ}$

ว ว

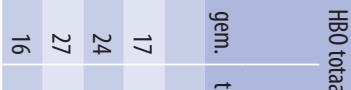

ว ว 


\section{Grenzen tussen $\mathrm{HBO}$ en MBO}

In dit hoofdstuk wordt kort ingegaan op de mate waarin de grenzen tussen $\mathrm{HBO}$ en $\mathrm{MBO}$ aan het vervagen zijn voor de sectoren gezondheidszorg en sociaal-agogisch onderwijs. We gaan in op het aandeel HGZO'ers en HSAO'ers dat werkzaam is in functies op MBO-niveau (paragraaf 5.I), evenals het aandeel van de schoolverlaters van corresponderende $\mathrm{MBO}$-opleidingen dat werkzaam is op $\mathrm{HBO}$-niveau (paragraaf 5.2).

\subsection{HGZO'ers en HSAO'ers in MBO-functies}

Zoals figuren 2.4 en 2.5 lieten zien, komen afgestudeerden van met name het HSAO relatief vaak terecht buiten het eigen kerndomein. Vaak gaat het om banen op $\mathrm{MBO}-$ niveau. Blijkbaar bestaat er voor een aantal banen geen scherpe grens tussen $\mathrm{MBO}$ en $\mathrm{HBO}$, met name bij het $\mathrm{HSAO} .{ }^{8}$ De volgende tabel laat de beroepen zien die deze HGZO'ers en HSAO'ers uitoefenen (alleen beroepen met een aandeel van tenminste $5 \%$ zijn vermeld).

\section{Tabel 5.1}

Vaakst voorkomende beroepen van HGZO'ers en HSAO'ers werkzaam op MBO-niveau (\%)

\begin{tabular}{|l|r|}
\hline Beroep & $\%$ \\
\hline Crècheleidster, bejaarden-, zwakzinnigenverzorgende & 22 \\
\hline Maatschappelijk sociaal-cultureel werker & 18 \\
\hline Leerling-verpleegkundige zorg, kinder-,bejaarden, zwakzinnigenverzorgende (lager) & 12 \\
\hline Sociaal-cultureel/maatschappelijk werker (excl. kinderbescherming/reclassering) & 8 \\
\hline
\end{tabular}

Zoals kan worden gezien, gaat het om beroepen die inhoudelijk gerelateerd zijn aan de inhoud van sociaal-agogische opleidingen, maar waarvoor een $\mathrm{HBO}$-opleiding geen strikte vereiste is. Tabel 5.2 laat de opleidingen zien die hierbij het sterkst zijn vertegenwoordigd (alleen opleidingen met een aandeel van ten minste IO\% zijn vermeld). Daarin is te zien dat met name afgestudeerden van HBO Sociaal Pedagogische Hulpverlening relatief vaak in een functie terecht komen waar ten minste een $\mathrm{MBO}$ niveau wordt vereist.

8. In zekere zin is het logisch dat de grenzen tussen $\mathrm{MBO}-\mathrm{HBO}$-opleidingen tamelijk vaag zijn, omdat het in beide gevallen om sterk beroepsgerichte opleidingen gaat. Dit in tegenstelling tot het WO. 
Tabel 5.2

$\mathrm{HGZO}$ en HSAO opleidingen waarbij men het vaakst op MBO-niveau werkzaam is (\%)

\begin{tabular}{|l|r|}
\hline Opleiding & $\%$ \\
\hline HBO B Sociaal Pedagogische Hulpverlening & 41 \\
\hline HBO B Pedagogiek & 14 \\
\hline HBO B Maatschappelijk Werk en Dienstverlening & 11 \\
\hline HBO B Culturele en Maatschappelijke Vorming & 10
\end{tabular}

\subsection{MBO'ers in HBO-functies}

We hebben gezien dat een aanzienlijk deel van met name HSAO'ers terecht komt in functies die ei-genlijk waren bestemd voor MBO'ers. Een interessante vervolgvraag is hoeveel MBO'ers van de overeenkomstige sectoren in functies terecht komen die eigenlijk HBO-functies zijn. Tabel 5.3 geeft hiervan een beeld.

\section{Tabel 5.3}

Betaald werkende gediplomeerden MBO-BOL niveau 4 naar vereist opleidingsniveau, 2005-2009 (\%)

\begin{tabular}{|c|c|c|c|}
\hline \multirow{2}{*}{$\begin{array}{l}\text { Huidige functie vereist opleidingsniveau } \\
\text { werkgever }\end{array}$} & \multicolumn{2}{|c|}{ Sector } & \multirow[t]{2}{*}{ Totaa } \\
\hline & MBO gezondheidszorg & MBO gedrag \& maatschappij & \\
\hline $\mathrm{HBO}$ of WO & 4,3 & 4,7 & 4,5 \\
\hline MBO-BOL/BBL niveau 3 of 4 & 88,1 & 84,7 & 86,3 \\
\hline MBO-BOL/BBL niveau 1 of 2 & 3,1 & 2,9 & 3,0 \\
\hline HAVO of VWO & 0,6 & 1,0 & 0,8 \\
\hline VMBO, VBO of MAVO & 3,8 & 5,1 & 4,5 \\
\hline Basisonderwijs & 0,1 & 1,7 & 0,9 \\
\hline Totaal & 100,0 & 100,0 & 100,0 \\
\hline
\end{tabular}

Iets minder dan $5 \%$ van de gediplomeerden van MBO-BOL niveau 4 zorg- en welzijnsopleidingen komt na het verlaten van de opleiding in een functie terecht waarvoor aanvankelijk minimaal een $\mathrm{HBO}$-opleiding werd vereist. Dit lijkt misschien niet zo veel, maar dit aandeel is ruim vier keer zo hoog als het aandeel HGZO'ers en HSAO'ers dat in functies terechtkomt op WO-niveau. Blijkbaar is de grens tussen $\mathrm{MBO}$ en $\mathrm{HBO}$ minder scherp dan tussen $\mathrm{HBO}$ en WO. Hierdoor kan worden gesteld dat er concurrentie bestaat tussen MBO'ers en HBO'ers.

Tabel 5.4 laat voor de gediplomeerden van de MBO-BOL niveau 4 opleidingen binnen de sectoren gezondheidszorg en gedrag $\&$ maatschappij, die terecht komen in functies die eigenlijk waren be-stemd voor HBO'ers, de meest voorkomende beroepen zien (alleen beroepen met een aandeel van ten minste $5 \%$ zijn vermeld). Daarin zien we dat bij de beroepen sociaal-cultureel/maatschappelijk werker en verpleegkundige ziekenhuis/ambulance relatief het vaakst MBO-BOL niveau 4 afgestu-deerden werken in 
een $\mathrm{HBO}$ functie. Het verschil met de andere MBO-BOL niveau 4 opleidingen is echter vrij klein.

\section{Tabel 5.4}

Meest voorkomende beroepen van BOL niveau 4 gezondheidszorg en gedrag \& maatschappij schoolverlaters werkzaam op HBO-niveau (\%)

\begin{tabular}{|l|r|}
\hline Beroep & $\%$ \\
\hline Sociaal-cultureel/maatschappelijk werker (excl. kinderbescherming/reclassering) & 11 \\
\hline Verpleegkundige ziekenhuis/ambulance & 10 \\
\hline Maatschappelijk sociaal-cultureel werker & 8 \\
\hline Zwakzinnigenverzorgende & 6 \\
\hline Bedrijfsorganisatiedeskundige, personeelsorganisatieadviseur & 6 \\
\hline Wijk-/school-/particulier/ziekenhuis verpleegkundige & 5
\end{tabular}

Tabel 5.5 laat de belangrijkste opleidingen zien van de betreffende onderschoolde MBO'ers (alleen opleidingen met een aandeel van ten minste IO\% zijn vermeld). Hierin zien we dat met name afge-studeerden van de MBO-BOL niveau 4 opleidingen Sociaal-pedagogisch werker en Verpleegkundige relatief vaak in een functie terecht komen waarvoor door de werkgever minimaal een $\mathrm{HBO}$ niveau werd vereist.

Het beroep maatschappelijk sociaal-cultureel werker en het beroep sociaal-cultureel/ maatschappelijk werker (excl. kinderbescherming/reclassering) zijn grensberoepen, want volgens sommige onderbe-nutte HSAO'ers zijn deze beroepen eigenlijk bedoeld voor MBO'ers en volgens sommige onder-schoolde MBO'ers zijn deze beroepen eigenlijk bedoeld voor HBO'ers.

\section{Tabel 5.5}

BOL niveau 4 gezondheidszorg en gedrag \& maatschappij opleidingen waarbij men het vaakst op HBO-niveau werkzaam is (\%)

\begin{tabular}{|l|l|}
\hline Opleiding & $\%$ \\
\hline BOL MKF Sociaal-pedagogisch werker & 30 \\
\hline BOL MKF Verpleegkundige & 27 \\
\hline BOL MKF Sociaal-juridisch medewerker arbeidsvoorziening/personeelswerk & 12 \\
\hline
\end{tabular}





\section{Conclusie}

Hoewel afgestudeerden van het HGZO en het HSAO net als de meeste HBO'ers enige last hebben van de conjunctuur, zal de vraag naar zorg naar verwachting in de toekomst alleen toenemen. Hierbij kunnen echter wel een aantal kanttekeningen worden geplaatst. HSAO'ers en in toenemende mate afgestudeerden van HGZO verpleegkunde opleidingen werken relatief vaak onder hun eigen niveau. Ook voor het $\mathrm{HBO}$ als geheel is er sprake van een afname in de mate van tevredenheid over de aan-sluiting tussen de $\mathrm{HBO}$ opleiding en het gevonden werk. Men werkt steeds vaker in tijdelijke en/of parttime functies. De inkomenssituatie van afgestudeerden lijkt in het afgelopen decennium in structurele zin nauwelijks te zijn veranderd. Verder doen tegen de algemene HBO-trend in, HGZO'ers en HSAO'ers steeds vaker aan bijscholing.

De toekomstige arbeidsmarktperspectieven zijn zowel voor het HGZO als het HSAO vrij goed te noemen, hoewel het HGZO hier beduidend beter scoort. Dit geldt overigens voor de gezondheidsop-leidingen op alle niveaus, dus zowel op het $\mathrm{HBO}$ als het $\mathrm{MBO}$ en WO. Op HBO-niveau zijn met name de arbeidsmarktperspectieven voor HGZO-verpleegkunde en -radiologie tot 2014 zeer goed.

Op basis van algemene en sectorspecifieke trends is er gekeken naar de vereiste competenties voor HGZO en HSAO afgestudeerden. Er is een aantal competenties waarvan het vereiste niveau de afge-lopen jaren significant is gestegen. Slechts één daarvan is zowel voor afgestudeerden van het HGZO als het HSAO significant gestegen: het vermogen om Informatie- \& Communicatietechnologie gebrui-ken. Gezien de trend dat technologische ontwikkelingen steeds belangrijker worden in de zorg- en welzijnssector is dit niet verwonderlijk. Competenties waarvan het vereiste niveau alleen voor het HGZO significant is gestegen:

- Kennis van eigen vakgebied

- Vermogen om vakkennis in de praktijk toe te passen

- Vermogen om problemen en kansen te signaleren

- Vermogen om verbanden te leggen tussen verschillende zaken (ook HBO trend)

- Vermogen om logisch te redeneren

- Vermogen om conform budget, planning of richtlijnen te werken (ook HBO trend) 
- Vermogen om knopen door te hakken

- Vermogen om nieuwe ideeën en oplossingen te bedenken

- Vermogen om nieuwe dingen te leren

- Vermogen om capaciteiten van anderen aan te spreken (ook HBO trend)

- Bereidheid om eigen en andermans ideeën ter discussie te stellen

Competenties waarvan het vereiste niveau alleen voor het HGZO significant is veranderd:

- Kennis van andere vakgebieden (gedaald)

- Vermogen om hoofd- van bijzaken te onderscheiden (gedaald)

Ervaren competentietekorten geven aan waar hogescholen in de toekomst meer aandacht aan zouden kunnen besteden bij de inhoud van het economische onderwijs. De analyses wijzen uit dat van de volgende competenties waarvan het vereiste niveau significant is gestegen voor afgestudeerden van het HGZO, tevens het competentietekort significant stijgt: vermogen om problemen en kansen te signaleren $30 \%$ van de HGZO afgestudeerden ervaart een tekort), vermogen om verbanden te leggen tussen verschillende zaken ( $33 \%$ ervaart een tekort), vermogen om logisch te redeneren ( $23 \%$ ervaart een tekort), vermogen om nieuwe dingen te leren ( $16 \%$ ervaart een tekort), bereidheid om eigen en andermans ideeën ter discussie te stellen (27\% ervaart een tekort). Van de twee competenties waar HSAO afgestudeerden een significant stijgend vereist niveau ervaren, verandert het compe-tentietekort niet significant.

Interessant genoeg toont een aantal competenties een toenemend percentage met een tekort onder HGZO'ers, terwijl geen sprake is van een toename in het vereiste niveau. Dit geldt voor het vermogen om informatie te vergaren en om productief met anderen samen te werken.

Ten slotte is uit analyses gebleken dat de grens tussen het $\mathrm{HBO}$ en $\mathrm{MBO}$ bij functies in de zorg- en welzijnsstudies niet altijd even duidelijk is. Met name afgestudeerden van HBO Sociaal Pedagogische Hulpverlening komen relatief vaak in een functie terecht die 'eigenlijk' op MBO niveau is, en afgestu-deerden van de MBO-BOL niveau 4 opleidingen Sociaal-pedagogisch werker en Verpleegkundige komen relatief vaak in een functie terecht die 'eigenlijk' op HBO niveau is. Het beroep maatschappelijk sociaal-cultureel werker en het beroep sociaal-cultureel/maatschappelijk werker (excl. kinderbe-scherming/reclassering) zijn grensberoepen, want volgens sommige onderbenutte HSAO'ers zijn deze beroepen eigenlijk bedoeld voor MBO'ers en volgens sommige onderschoolde MBO'ers zijn deze beroepen eigenlijk bedoeld voor HBO'ers. 


\section{Literatuur}

Dekker, H., Vonk, R., Vries, C.W. de, Wagenaar, S. \& Renekers, N.C.F (2002), Vraagsturing als competentie. Eindrapportage. Utrecht: Kessels \& Smit, The Learning Company.

Ministerie van Onderwijs, Cultuur en Wetenschap (2011), Hoofdlijnenakkoord OCW - HBOraad, Den Haag: OCW.

Ministerie van Volksgezondheid, Welzijn en Sport (2007), Niet van later zorg, Den Haag: VWS.

ROA (2009), De arbeidsmarkt naar opleiding en beroep tot 2014, Maastricht: Researchcentrum voor Onderwijs en Arbeidsmarkt.

Scherpbier, A., et al (2010), Monitor beroepskeuzes, beroepsvorming en loopbanen in de geneeskunde, Een eerste schets, z.pl.

Vereniging van Nederlandse Vrouwelijke Artsen (2010), Feiten en cijfers over (aanstaande) artsen m/v, Nijmegen: UMC St. Radboud.

Vliet, K. van, et al (2004), Toekomstverkenning ten behoeve van een beroepenstructuur in zorg en welzijn, Verwey-Jonker Instituut 



\section{Bijlagen}

\section{Bijlage 1}

Clustering van opleidingen in de sector HGZO

\begin{tabular}{|c|c|c|c|}
\hline Verpleegkunde & Bewegingsstudies & Paramedisch & Overig \\
\hline $\begin{array}{l}\text { HBO Opleiding tot } \\
\text { verpleegkundige }\end{array}$ & HBO Ergotherapie & HBO Fysiotherapie & $\begin{array}{l}\text { HBO Opleiding van kader in de } \\
\text { gezondheidszorg }\end{array}$ \\
\hline $\begin{array}{l}\text { HBO B Opleiding tot } \\
\text { Verpleegkundige }\end{array}$ & HBO Logopedie & HBO B Opl. tot Fysiotherapeut & $\begin{array}{l}\text { HBO Lerarenopleiding } \\
\text { verpleegkunde (e gr.) }\end{array}$ \\
\hline $\begin{array}{l}\text { HBO Opleiding } \\
\text { verpleegkundige } \\
\text { maatschappelijke } \\
\text { gezondheidszorg }\end{array}$ & $\begin{array}{l}\text { HBO B Opleiding voor } \\
\text { Logopedie }\end{array}$ & $\begin{array}{l}\text { HBO Opleiding } \\
\text { oefentherapeut-Cesar }\end{array}$ & HBO Voeding en dietetiek \\
\hline $\begin{array}{l}\text { HBO B Opl. Verpleegkundige } \\
\text { maatschappelijke } \\
\text { gezondheidszorg }\end{array}$ & $\begin{array}{l}\text { HBO B Opleiding voor } \\
\text { Ergotherapie }\end{array}$ & HBO Bewegingstechnologie & HBO Opleiding mondhygienist \\
\hline $\begin{array}{l}\text { HBO M Advanced Nursing } \\
\text { Practice }\end{array}$ & HBO Optometrie & $\begin{array}{l}\text { HBO B Opl. Bewegingsagogie/ } \\
\text { Psychomotorische Therapie }\end{array}$ & $\begin{array}{l}\text { HBO Medisch beeldvormen- } \\
\text { de/radiotherapeutische } \\
\text { technieken }\end{array}$ \\
\hline \multirow{13}{*}{$\begin{array}{l}\text { HBO Opleiding tot } \\
\text { verpleegkundige met } \\
\text { vrijstelling }\end{array}$} & HBO Opleiding tot orthoptist & $\begin{array}{l}\text { HBO Bewegingsagogie/ } \\
\text { psychomotorische therapie }\end{array}$ & HBO B Voeding en Diëtiek \\
\hline & HBO B Orthoptie & HBO B Bewegingstechnologie & HBO B Management in de Zorg \\
\hline & & HBO Opleiding podotherapie & $\begin{array}{l}\text { HBO B Medisch } \\
\text { Beeldvormende en } \\
\text { Radiotherapeutische } \\
\text { Technieken }\end{array}$ \\
\hline & & $\begin{array}{l}\text { HBO Opleiding } \\
\text { oefentherapeut-Mensendieck }\end{array}$ & $\begin{array}{l}\text { HBO B Sport, Gezondheid en } \\
\text { Management }\end{array}$ \\
\hline & & HBO B Oefentherapie Cesar & HBO B Opleiding Mondhygiëne \\
\hline & & HBO B Opleiding Podotherapie & $\begin{array}{l}\text { HBO Antroposofische } \\
\text { gezondheidszorg }\end{array}$ \\
\hline & & & $\begin{array}{l}\text { HBO B Antroposofische } \\
\text { Gezondheidszorg }\end{array}$ \\
\hline & & & HBO B Huidtherapie \\
\hline & & & $\begin{array}{l}\text { HBO B Opl. van Kader in de } \\
\text { Gezondheidszorg }\end{array}$ \\
\hline & & & HBO Huidtherapie \\
\hline & & & HBO B Farmakunde \\
\hline & & & HBO B Verloskunde \\
\hline & & & HBO Radiologisch laborant \\
\hline
\end{tabular}


Tabel B2

Vijf kernindicatoren voor HGZO en HSAO Bachelor-opleidingen, 2006-2010

\begin{tabular}{|c|c|c|c|c|c|c|}
\hline HGZO/HSAO Bachelor-opleiding & Werkloosheid & $\begin{array}{r}\text { Werkzaam in } \\
\text { kerndomein } \\
\%\end{array}$ & $\begin{array}{r}\text { gem. Bruto } \\
\text { uurloon }\end{array}$ & $\begin{array}{r}\text { Spijt } \\
\text { opleiding } \\
\%\end{array}$ & $\begin{array}{r}\text { Tevreden } \\
\text { met } \\
\text { functie } \\
\%\end{array}$ & Aantal \\
\hline Antroposofische Gezondheidszorg & 14,2 & 30,4 & 11,9 & 16,8 & 34,7 & 62 \\
\hline Bewegingstechnologie & 3,4 & 64,2 & 15,3 & 34,6 & 59,6 & 126 \\
\hline Creatieve therapie & $\mathrm{x}$ & $\mathrm{x}$ & $x$ & $x$ & $x$ & 17 \\
\hline Creatieve Therapie & 10,2 & 57,1 & 14,4 & 14,4 & 57,0 & 356 \\
\hline Culturele en Maatschappelijke Vorming & 8,4 & 40,7 & 12,6 & 42,2 & 50,2 & 810 \\
\hline Farmakunde & 4,3 & 71,3 & 15,0 & 16,3 & 65,9 & 60 \\
\hline Godsdienst-pastoraal werk & $\mathrm{x}$ & $x$ & $x$ & $\mathrm{x}$ & $x$ & 1 \\
\hline Huidtherapie & 1,4 & 83,9 & 13,5 & 22,5 & 77,5 & 142 \\
\hline Maatschappelijk Werk en Dienstverlening & 4,4 & 75,9 & 14,4 & 15,8 & 67,4 & 1745 \\
\hline Management in de Zorg & 0,0 & 73,9 & 18,5 & 0,0 & 79,1 & 20 \\
\hline $\begin{array}{l}\text { Medisch Beeldvormende en } \\
\text { Radiotherapeutische Tech-nieken }\end{array}$ & 3,2 & 95,4 & 13,4 & 10,9 & 78,4 & 243 \\
\hline Muziektherapie & $\mathrm{x}$ & $\mathrm{x}$ & $x$ & $x$ & $x$ & 7 \\
\hline Oefentherapie Cesar & 2,5 & 89,6 & 15,7 & 26,3 & 85,7 & 68 \\
\hline Oefentherapie Cesar/Mensendieck & 5,9 & 79,7 & 16,8 & 20,0 & 65,6 & 38 \\
\hline $\begin{array}{l}\text { Opl. Bewegingsagogie/Psychomotorische } \\
\text { Therapie }\end{array}$ & 2,8 & 72,6 & 13,6 & 12,6 & 62,6 & 153 \\
\hline Opl. tot Fysiotherapeut & 2,5 & 92,7 & 17,7 & 7,9 & 80,1 & 1972 \\
\hline Opl. van Kader in de Gezondheidszorg & 0,0 & 69,9 & 19,5 & 4,5 & 61,6 & 59 \\
\hline $\begin{array}{l}\text { Opl. verpleegkundige maatschappelijke } \\
\text { gezondheidszorg }\end{array}$ & 0,0 & 91,7 & 23,0 & 3,8 & 77,1 & 26 \\
\hline $\begin{array}{l}\text { Opl. Verpleegkundige maatschappelijke } \\
\text { gezondheidszorg }\end{array}$ & 0,0 & 92,6 & 22,2 & 6,9 & 71,1 & 56 \\
\hline Opleiding Mondhygiëne & 0,7 & 95,8 & 17,1 & 14,5 & 77,5 & 229 \\
\hline Opleiding mondhygienist & $x$ & $x$ & $\mathrm{x}$ & $x$ & $x$ & 15 \\
\hline Opleiding Podotherapie & $\mathrm{x}$ & $x$ & $x$ & $x$ & $x$ & 12 \\
\hline Opleiding tot orthoptist & 0,0 & 96,8 & 14,9 & 3,2 & 81,3 & 28 \\
\hline Opleiding tot Verpleegkundige & 1,1 & 61,6 & 13,2 & 16,6 & 75,6 & 2222 \\
\hline Opleiding voor Ergotherapie & 1,4 & 88,0 & 14,5 & 10,0 & 76,5 & 429 \\
\hline Opleiding voor Logopedie & 2,5 & 91,4 & 13,9 & 11,4 & 75,2 & 642 \\
\hline Opleidingskunde & $\mathrm{x}$ & $x$ & $\mathrm{x}$ & $\mathrm{x}$ & $x$ & 16 \\
\hline Orthoptie & $\mathrm{x}$ & $\mathrm{x}$ & $x$ & $x$ & $x$ & 17 \\
\hline Pedagogiek & 5,1 & 60,0 & 13,2 & 16,2 & 57,1 & 949 \\
\hline Sociaal pedagogische hulpverlening & 0,0 & 71,2 & 12,3 & 24,5 & 59,6 & 21 \\
\hline Sociaal Pedagogische Hulpverlening & 3,0 & 52,8 & 13,0 & 23,2 & 64,3 & 2863 \\
\hline Sociaal-Juridische Dienstverlening & 4,2 & 66,8 & 15,5 & 24,4 & 64,0 & 603 \\
\hline Sport en Bewegen & 3,5 & 38,5 & 12,1 & 35,4 & 59,5 & 114 \\
\hline Sport, Gezondheid en Management & 8,4 & 48,4 & 13,0 & 46,9 & 60,4 & 209 \\
\hline Verloskunde & 0,0 & 100,0 & 20,8 & 0,0 & 93,3 & 52 \\
\hline Voeding en Diëtiek & 6,9 & 80,3 & 13,8 & 20,5 & 71,6 & 374 \\
\hline Totaal HGZO Bachelor & 2,3 & 79,5 & 15,2 & 13,5 & 76,0 & 7.254 \\
\hline
\end{tabular}




\begin{tabular}{|l|r|r|r|r|r|r|}
\hline HGZO/HSAO Bachelor-opleiding & Werkloosheid & $\begin{array}{r}\text { Werkzaam in } \\
\text { kerndomein }\end{array}$ & $\begin{array}{r}\text { gem. Bruto } \\
\text { uurloon }\end{array}$ & $\begin{array}{r}\text { Spijt } \\
\text { opleiding }\end{array}$ & $\begin{array}{r}\text { Tevreden } \\
\text { met } \\
\text { functie }\end{array}$ & Aantal \\
\hline Totaal HSAO Bachelor & $\%$ & $\%$ & $€$ & $\%$ & $\%$ & $n$ \\
\hline Totaal HBO Bachelor & 4,6 & 60,0 & 13,6 & 21,7 & 62,8 & 7.502 \\
\hline
\end{tabular}

$X=$ te weinig waarnemingen (in de periode $2006-2010$ in totaal minder dan 20 respondenten)

Opleidingen waarvoor in de periode 2006-2010 in een of meerdere jaren geen gegevens beschikbaar waren, zijn gearceerd.

Bron: HBO-Monitor 2006-2010

Toelichting

- Werkloosheid: Het werkloosheidspercentage heeft betrekking op de werkloze beroepsbevolking: schoolverlaters zonder werk (of met werk van minder dan 12 uur per week) die op zoek zijn naar betaald werk. Daarbij is tevens als voorwaarde gesteld dat de maatschappelijke positie niet scholier of student is.

- Kerndomein: Het percentage dat aangeeft dat het door de werkgever vereiste opleidingsniveau minimaal HBO is en dat de door de werkgever vereiste opleidingsrichting overeenkomt met of verwant is aan de eigen opleidingsrichting.

- Bruto uurloon: Dit betreft het gemiddelde bruto inkomen in de hoofdfunctie. Dit is inclusief toeslagen maar exclusief inkomen uit overwerk. Er is hier niet gecorrigeerd voor verschillen in leeftijd van de schoolverlaters; wel voor inflatie.

- Spijt opleiding: Het percentage dat aangeeft achteraf gezien voor een andere opleiding op hetzelfde of ander niveau te hebben willen kiezen.

- Tevredenheid: Hoe tevreden bent u met uw huidige functie ( 1 'zeer ontevreden' tot en met 5 'zeer tevreden'. Vermeld is het percentage van antwoordcategorie 4 en 5 . 